\title{
LITOFÁCIES E SIGNIFICADO PALEOAMBIENTAL DOS SEDIMENTOS ITARARÉ NA REGIÃO CAPIVARI-RAFARD, ESTADO DE SÃO PAULO
}

\author{
Setembrino PETRI
}

\begin{abstract}
RESUMO
Este trabalho se refere à descrição litológica e estudos das estruturas sedimentares presentes nos testemunhos de seis poços para água subterrânea, perfurados pelo Instituto Geológico da Secretaria do Meio Ambiente do Estado de São Paulo, em torno das cidades de Capivari e Rafard, na região do médio rio Tietê, Estado de São Paulo. Estes poços, que atingiram profundidades entre 101,4 e $310 \mathrm{~m}$, foram totalmente testemunhados. O estudo desses testemunhos, associado a dados obtidos no campo, conduziram à proposição de uma paleogeografia durante parte do Permiano. As rochas estudadas pertencem ao Subgrupo Itararé que, na bacia do Paraná, se distribui do Neocarbonífero ao Mesopermiano. Além desses seis poços, foram referidos no presente trabalho, mas não descritos, mais sete poços perfurados pelo Instituto Geológico na região do médio Tietê, entre os anos de 1985 e 1990, também com testemunhagem completa, sempre envolvendo o Subgrupo Itararé.
\end{abstract}

\begin{abstract}
This paper deals with lithological description and comparisons of cores from six thoroughly cored groundwater wells. They range in depth from 101,4 to $310 \mathrm{~m}$. They were drilled between the years 1985 and 1990, near the towns of Capivari and Rafard, in the middle Tietê river valley, State of São Paulo, Brasil, by the "Instituto Geológico, Secretaria do Meio Ambiente". The drilled sediments are Permian in age and belong to the Permo-Carboniferous Itararé Subgroup. Seven additional wells in the middle Tietê valley, also drilled between 1985 and 1990 by the "Instituto Geológico", are referred to but not described. The interpretation of the lithologies and sedimentary structures of these sediments as well as addicional data from field researches allow a paleogeographic interpretation and reconstruction of the environments of deposition, in Permian times, around the Capivari and Rafard urban areas. A sea would have been persistently present in the area, its sediments being laid down in offshore and submarine fan conditions.
\end{abstract}

\section{INTRODUÇÃO}

De 1985 a 1990, o Instituto Geológico da Secretaria do Meio Ambiente do Estado de São Paulo (IG-SMA) perfurou treze poços para água subterrânea, com testemunhagem completa, todos localizados no vale do médio Tietê. A maioria está localizada em duas áreàs, seis na de Capivari-Rafard e três na de Tietê (Fig. 1).

A profundidade máxima atingida por estes poços foi de $310 \mathrm{~m}$ e a mínima, $80 \mathrm{~m}$. As colunas litológicas de todos foram por nós minuciosamente descritas e registradas. No presente artigo só estão relacionados os poços perfurados na região Capivari-Rafard. Em artigo subseqüente serão relacionados os perfurados na região de Tietê.

Os objetivos destes artigos, com referência aos poços perfurados, são os seguintes: a) divulgar as colunas litológicas, b) tecer considerações sobre o procedimento usado para as descrições, c) análise comparativa. Esta aná- lise servirá de subsídio para trabalhos que estamos realizando, em paralelo, visando considerações paleogeográficas que poderão contribuir para o aprimoramento de pesquisas de aqüíferos.

\section{CONSIDERAÇÕES SOBRE O REGISTRO E A DESCRIÇÃO DAS LITOGRAFIAS DOS POÇOS}

A - Nomenclatura dos poços - São referidos por uma letra, designativa do município ou do distrito onde o poço foi perfurado. Exemplo: $R$ para Rafard; $C$ para Capivari. Depois de um traço, seguem-se as letras IG, significando que o poço foi perfurado pelo Instituto Geológico. O número que vem a seguir se refere ao ano em que foi iniciado. Por exemplo, $R-I G / 85$ significa que o poço foi perfurado pelo IG-SMA em 1985 , no município de Rafard. Quando dois poços são iniciados no mesmo ano e no mesmo 
TABELA 1 - Relação dos poços perfurados pelo IG-SMA, para água subterrânea, de 1985 a 1990.

\begin{tabular}{|c|c|c|c|c|c|}
\hline \multirow{2}{*}{$\begin{array}{l}\text { N. na } \\
\text { Figura }\end{array}$} & \multirow{2}{*}{ Localidade } & \multirow{2}{*}{ Poço } & \multirow{2}{*}{$\begin{array}{c}\text { Folha } \\
\text { (IBGE 1:50.000) }\end{array}$} & \multicolumn{2}{|c|}{ Coordenadas UTM } \\
\hline & & & & $\mathrm{Km} \mathrm{E}$ & $\mathrm{Km} \mathrm{N}$ \\
\hline 01 & Itu & It-IG/85 & Salto & 259,55 & 7428,7 \\
\hline 02 & Porto Feliz & PF-IG/85 & Boituva & 242,7 & 7425,25 \\
\hline 03 & Rafard & R-IG/85 & Porto Feliz & 241,45 & 7451,65 \\
\hline 04 & Mombuca & M-IG/85 & Capivari & 234,95 & 7462,1 \\
\hline 05 & Sete Fogões & SF-IG/85 & Porto Feliz & 232,7 & 7443,85 \\
\hline 06 & Araçoiaba & A-IG/86 & Salto de Pirapora & 231,6 & 7392,8 \\
\hline 07 & Capivari & C-IG/86 & Porto Feliz & 234,4 & 7452,0 \\
\hline 08 & Jumirim & $\mathrm{J}-\mathrm{IG} / 86$ & Laranjal Paulista & 213,7 & 7443,95 \\
\hline 09 & Capivari & C-IG/87 & Americana & 244,1 & 7455,0 \\
\hline 10 & Tietê & T-IG/87 & Porto Feliz & 223,7 & 7443,55 \\
\hline 11 & Capivari & C-IG/89 & Salto & 244,5 & 7451,5 \\
\hline 12 & Capivari & C2-IG/89 & Americana & 245,8 & 7456,55 \\
\hline 13 & Capivari & C-IG/90 & Porto Feliz & 243,3 & 7453,6 \\
\hline
\end{tabular}

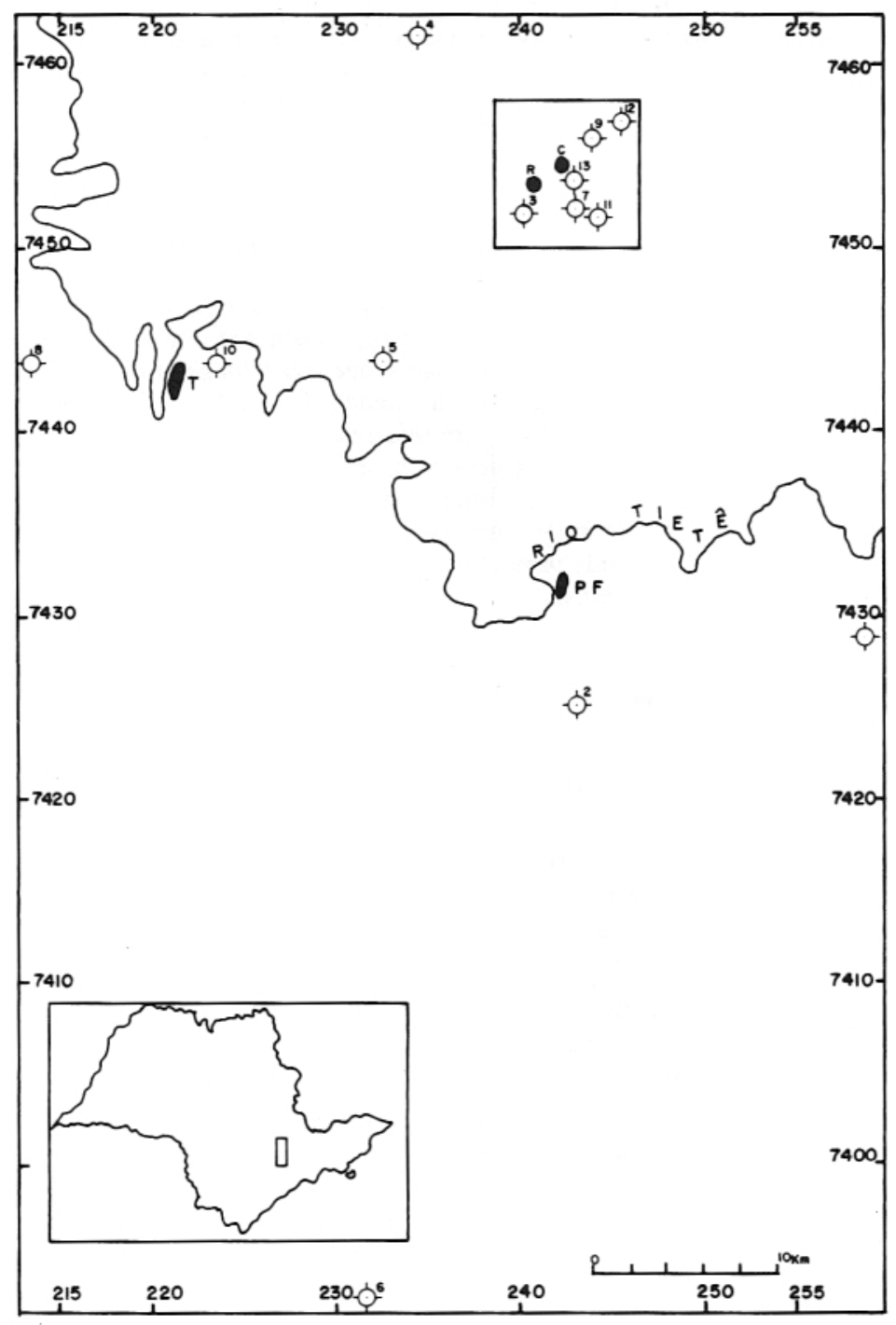

FIGURA 1 - Localização dos poços perfurados pelo IG-SMA de 1985 a 1990.

FP - Cidade de Porto Feliz; T - Cidade de Tietê; C - Cidade de Capivari; R - Cidade de Rafard; os números se referem aos poços, discriminados na Tabela 1. 


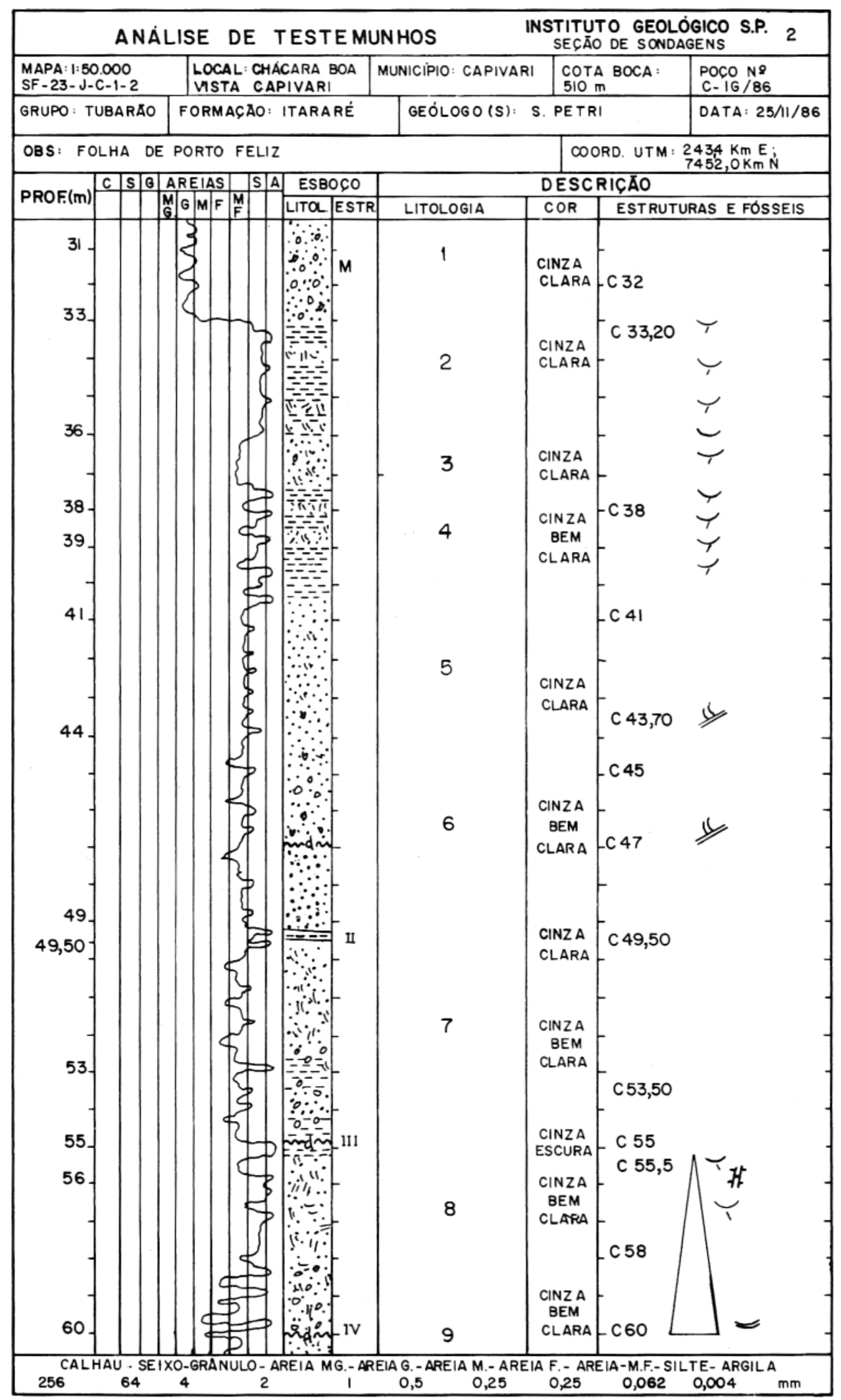

FIGURA 2 - Exemplo de ficha de análise de testemunhos. Para o significado das legendas, ver Figuras 4. Os números romanos remetem ao verso da ficha, onde estruturas são mais detalhadas. 


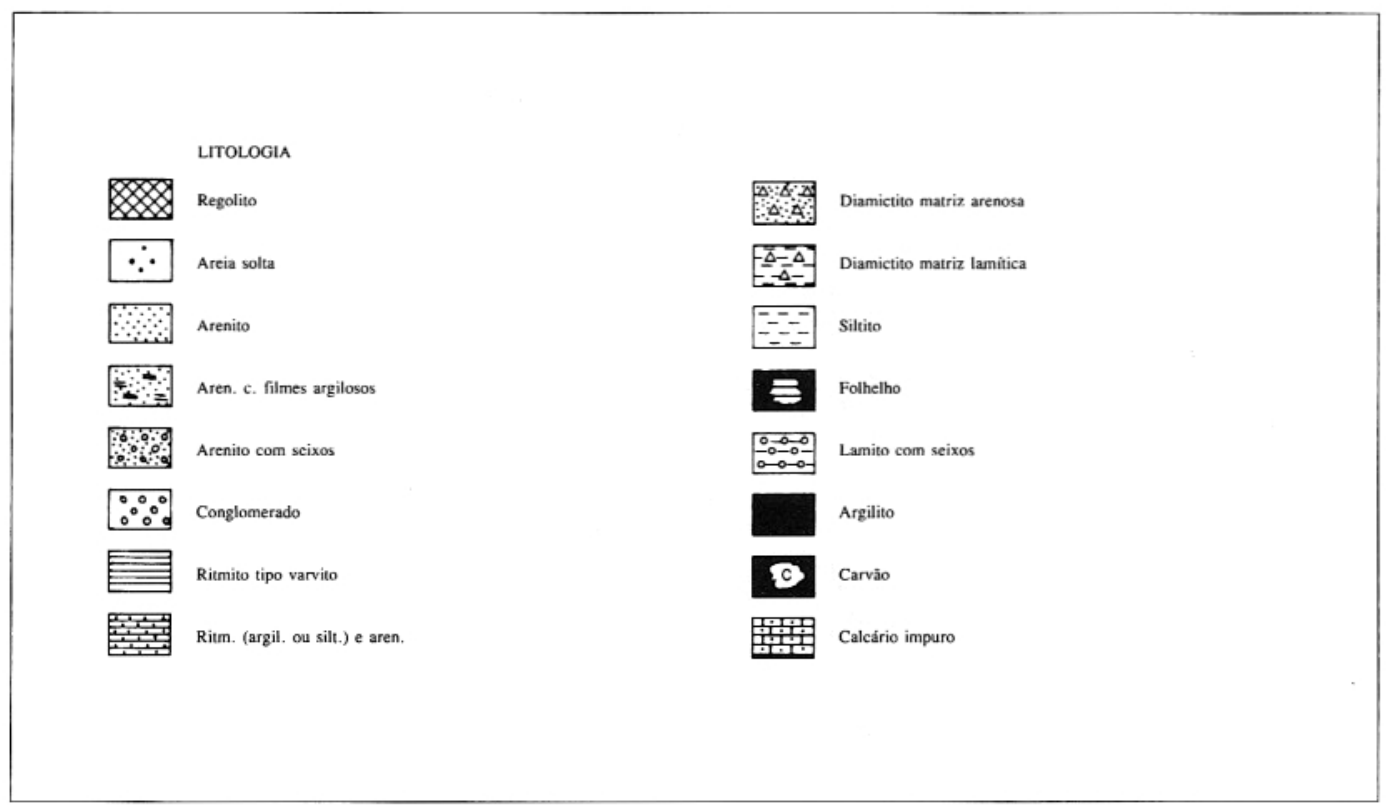

FIGURA 3 - Poços da região Capivari-Rafard - Legenda geral para as litologias.

\begin{tabular}{|c|c|c|c|}
\hline 2 & Dobra deitada & 2 & Filme de argil. diminuindo p. o lado \\
\hline ומשרזה & Dobra com microdobras & $\sim$ & Filme obliquo ao testemunho \\
\hline$\Rightarrow$ & Filmes inclin. e horiz. & $\Sigma$ & Falha inversa \\
\hline V & Ripas inclinadas & (C) & Argil, enrolado sobre si mesmo \\
\hline$\varphi$ & Fósseis vegetais & $x$ & Filmes caóticos \\
\hline$\mu 4$ & Argilito amarrotado & & Ampla ondulação envolvendo todo o test. \\
\hline 八 & Evocativo "tepee" & $\approx$ & Filmes horiz $\mathrm{e}$ ven. \\
\hline 口ם & Placas isoladas de argil. & >7 & Climbing irreg. $\mathrm{e}$ imperfeitos \\
\hline$\Omega$ & Flame & $\infty$ & Concentração argilosa \\
\hline 22 & Marca ondulada assimétrica & $\because$ & Ripa isolada e torcida \\
\hline & Marca ondulada simétrica & 8 & Aren. separado obliqu/por filme \\
\hline $\begin{array}{r}\Delta, \Delta \\
0.8\end{array}$ & Linguas de aren. em diamic & - & Feixe de argil. horiz, e incl. \\
\hline $7 \mu$ & Filmes horiz, e vert. & 0 & Concreção epigenética \\
\hline$\infty$ & Brecha sedimentar & $\approx$ & Gdes ondulaçóes envolvendo toda a largura do testemunho \\
\hline 6\%) & Bolsāo de aren. grosso em mais fino & & Falhas convergentes \\
\hline A & Diápiro de argilito & (2) & Filmes envolvendo arcósio \\
\hline 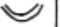 & Sinclinio & 9 & Pista \\
\hline$<<$ & Passagem lateral de aren. para lamito $c$. seixos & & Dobras e convolutas truncadas \\
\hline & Dique de aren. de cima & & Ripas isoladas dispostas $\mathrm{em}$ calha \\
\hline
\end{tabular}

FIGURA 4a - Poços da região Capivari-Rafard - Legenda geral para as estruturas. 


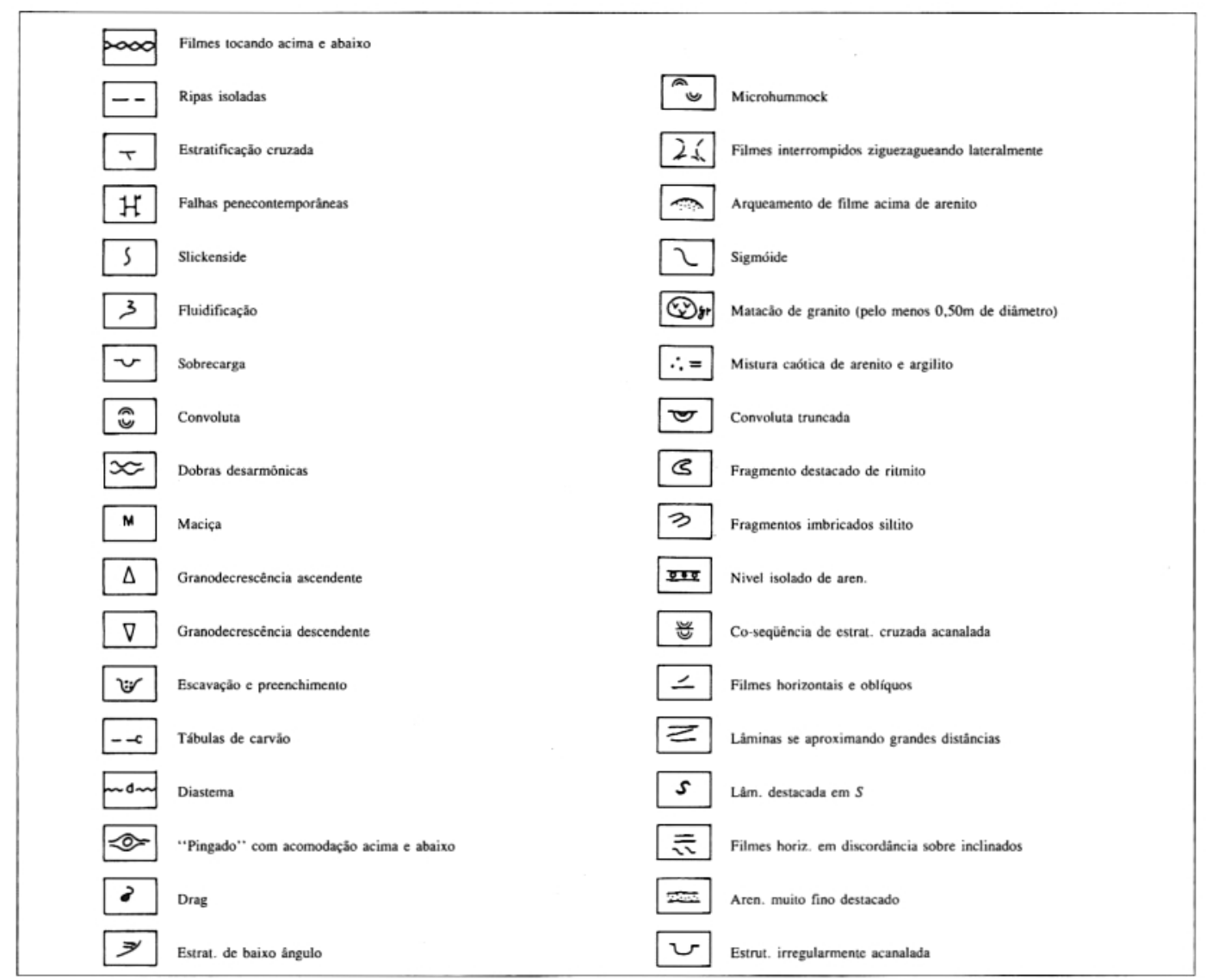

FIGURA 4b - Poços da região Capivari-Rafard - Legenda geral para as estruturas (cont.).

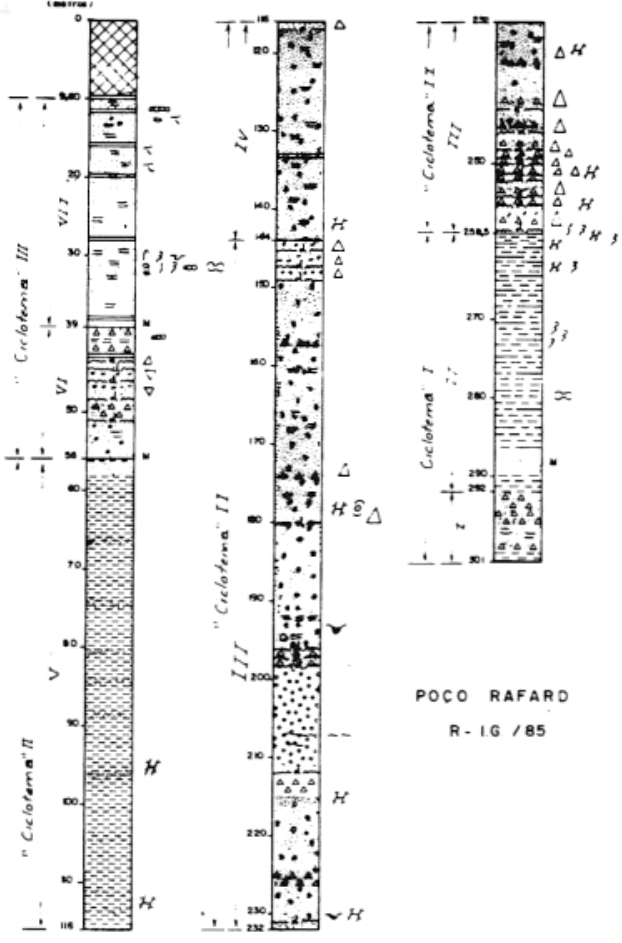

FIGURA 5 - Poço R-IG/85 - Perfil condensado.

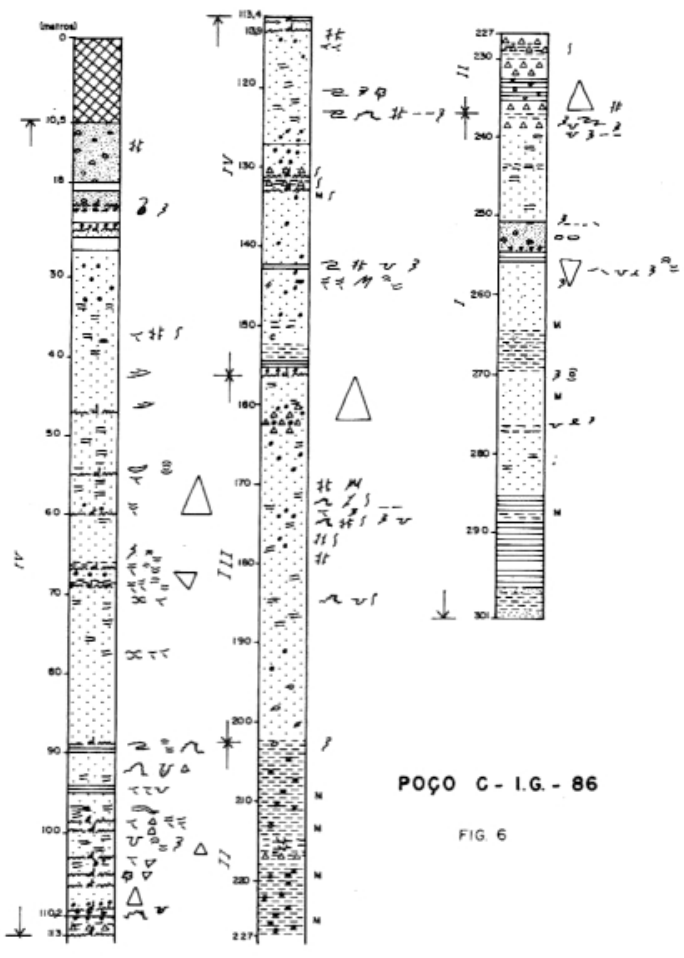

FIGURA 6 - Poço C-IG/86 - Perfil condensado. 
TABELA 2 - Exemplo de descrição pormenorizada de testemunhos (ficha no 13 do poço C2-IG/89).

\begin{tabular}{|c|c|c|c|c|c|c|c|}
\hline Local & Litologia & Seleção & Espessura & $\begin{array}{l}\text { Litologia } \\
\text { Associada }\end{array}$ & Estruturas & $\begin{array}{l}\text { Litologia: } \\
\text { acima/abáixo }\end{array}$ & Cor \\
\hline $\begin{array}{l}\mathrm{C} 2-\mathrm{IG} / 89 \\
60 \\
63 \\
65\end{array}$ & $\begin{array}{l}\text { Arenito } \\
\text { grosso a } \\
\text { médio } \\
\text { com } \\
\text { filmes de } \\
\text { freqüência } \\
\text { variável. } \\
\text { Pouca } \\
\text { matriz. } \\
\text { Friável. } \\
\text { Raras } \\
\text { ripas } \\
\text { isoladas } \\
\text { de carvão. }\end{array}$ & ma. & $5,50 \mathrm{~m}$ & $\begin{array}{l}\text { Arenito } \\
\text { médio. } \\
\text { Filmes } \\
\text { argilosos. } \\
\text { Carvão. }\end{array}$ & $\begin{array}{l}\text { Filmes caotic/distrib. Em } \\
\text { C2-60, na base, eles formam } \\
\text { uma faixa incl. de } 17 \mathrm{~cm} \text { de } \\
\text { compr. e larg. variáv., até } \\
\text { 4cm. Lateralmente p/cima esta } \\
\text { faixa torna-se caótica como } 1 \\
\text { novelo/lã desmanc. Ripas de } \\
\text { carvão são raras, curtas e } \\
\text { inter. De } 60 \text { a } 62 \mathrm{~m} \text { pratic. } \\
\text { desap. os filmes, que reap. de } \\
62 \text { a } 63 \mathrm{~m} \text {, onde eles estão } \\
\text { interromp. e conf. disp. Em } \\
\text { C2-65 o arenito grosso passa, } \\
\text { abaixo, p/aren. médio através } \\
\text { de dias. O arenito grosso de } \\
\text { cima exibe restos de plantas } \\
\text { carbon. de até } 9 \text { por } 2,5 \mathrm{~cm} \\
\text { conf. distribuídos. O arenito } \\
\text { médio é rico em filmes. Logo } \\
\text { no contato com o diastema, os } \\
\text { filmes formam dobras deit. } \\
\text { irreg. Línguas de argil. penet. } \\
\text { no arenito grosso a partir do } \\
\text { aren. de baixo. No restante da } \\
\text { superf. do diast., depos. de } \\
\text { arg. acomp. suas irregul. Mais } \\
\text { para baixo da superfície do } \\
\text { diast., os filmes exibem } \\
\text { grandes " exovelos } \\
\text { desmanchados", em esp. } \\
\text { irreg. que atingem } 10 \mathrm{~cm} \text {. } \\
\text { Abaixo os filmes são mais reg. } \\
\text { mas formam grandes } \\
\text { reticulados envolv. o aren., de } \\
\text { posição de início suboriz. e } \\
\text { depois incl., passando para } \\
\text { dobras comp., espraiadas } \\
\text { obliqu. }\end{array}$ & \begin{tabular}{|c} 
Acima: \\
Arcósio \\
Abaixo: \\
arenito \\
grosso \\
\\
\end{tabular} & \begin{tabular}{|l|} 
Arenito \\
grosso: \\
cinza- \\
rosado \\
(5YR \\
$8 / 1$ ) \\
Arenito \\
médio: \\
cinza- \\
claro \\
(N7). \\
Filmes: \\
cinza- \\
médio- \\
claros \\
(N6). \\
Carvão: \\
cinza- \\
escuro \\
(N3).
\end{tabular} \\
\hline
\end{tabular}

Abreviações Utilizadas na Tabela 2:

Caotic. - Caoticamente;

Distrib. - Distribuídos;

Incl. - Inclinada;

Compr. - Comprimento;

Larg. - Largura;

Variáv. - Variável;

p. - para;

Desmanc. - Desmanchado;

Inter. - Interrompidas;

Pratic. - Praticamente;

Desap. - Desaparecem;

Reap. - Reaparecem;

Interromp. - Interrompidos;

Conf. - Confusamente;

Disp. - Dispostos;

Diast. - Diastema;
Carbon. - Carbonizadas;

Deit. - Deitadas;

Irregul. - Irregulares;

Test. - Testemunho;

Argil. - Argilito;

Penet. - Penetram;

Superf. - Superfície;

Depos. - Depósitos;

Arg. - Argilito;

Acomp. - Acompanham;

Irregul. - Irregularidades;

Esp. - Espessuras;

Reg. - Regulares;

Envolv. - Envolvendo;

Suboriz. - Suborizontal;

Comp. - Compostas;

Obliqu. - Obliquamente. 
TABELA 3 - Poço R - IG/85 - Estruturas Sedimentares.

\begin{tabular}{|c|c|c|c|c|c|c|c|c|}
\hline $\begin{array}{l}\text { Boa Sep. } \\
\text { granul. }\end{array}$ & 9,$6 ; 11,5$ & $40 ; 40,6$ & & & $188 ; 224 ; 227$ & & & \multirow[t]{7}{*}{$\begin{array}{l}\text { Fluxos } \\
\text { laminares }\end{array}$} \\
\hline Estrat. cruzada & \begin{tabular}{|l|}
$13 ; 19$ \\
18,5 \\
\end{tabular} & & & & & 280 & 295 & \\
\hline $\mathrm{CC}$ & 17 & $47-40$ & & & $\begin{array}{l}227 ; 229 ; \\
236\end{array}$ & & & \\
\hline $\begin{array}{l}\text { Granod. } \\
\text { ascend. }\end{array}$ & & $44 ; 40$ & & $\begin{array}{l}116 ; 117 \\
143-144\end{array}$ & $\begin{array}{l}146-148 ; 236 \\
237 ; 241-258 \\
\end{array}$ & & & \\
\hline $\begin{array}{l}\text { Granod. } \\
\text { descend. }\end{array}$ & & $46-47$ & & & & & & \\
\hline CTO & 38 & & & & & $\begin{array}{l}261-263 \\
280 \\
\end{array}$ & & \\
\hline Ondul. desarm. & 34,5 & & $59-113$ & $\begin{array}{l}145 ; 162 ; 166 \\
176-177 ; 194 \\
216-230 ; 252 ; 256\end{array}$ & & & & \\
\hline Ripas isoladas & $\begin{array}{l}11,5 ; 13 ; \\
18,5 \\
\end{array}$ & 51 & & & & & & \multirow[t]{4}{*}{ Deslizes } \\
\hline Falhas atect. & & $52-55$ & $\begin{array}{l}57 ; 96 \\
113 \\
\end{array}$ & 142 & \begin{tabular}{|l|}
$178-180 ; 224$ \\
$227 ; 252-256$ \\
\end{tabular} & $\begin{array}{l}259- \\
263 \\
\end{array}$ & & \\
\hline Brechas sedim. & 12 & & & & & & & \\
\hline Convolutas & 31 & $48 ; 48,6$ & 57 & & 179,224 & & & \\
\hline CGSF & $\begin{array}{l}16-20 \\
30-32\end{array}$ & & & & & & & \multirow[t]{2}{*}{$\begin{array}{l}\text { Sedimentação } \\
\text { rápida }\end{array}$} \\
\hline MCL & 32 & & & $\begin{array}{l}193 ; 197 \\
207 ; 216 \\
\end{array}$ & $\begin{array}{l}259-267 ; 272 \\
291-292\end{array}$ & & $\begin{array}{l}294,5 \\
300 \\
\end{array}$ & \\
\hline Diastema & & $\begin{array}{l}43-46 \\
52\end{array}$ & & 117 & $\begin{array}{l}145-148,5 ; \\
180 ; 188 ; 196 ; \\
197,5 ; 207 ; 212 ; \\
231 ; 236 ; 244- \\
255 ; 258,5 \\
\end{array}$ & & & \multirow[t]{2}{*}{ Erosão } \\
\hline $\begin{array}{l}\text { Escav./ } \\
\text { preench. }\end{array}$ & & & & $\begin{array}{l}193 ; 194 ; \\
230 ; 236\end{array}$ & & & & \\
\hline Frag/carvão & & & & & 207 & & & Orgânica \\
\hline Maciça & & $29-56$ & & & 217 & $\begin{array}{l}286 \\
290 \\
\end{array}$ & & $\begin{array}{l}\text { Origens } \\
\text { diversas } \\
\end{array}$ \\
\hline Intervalos & $9,6-39$ & $39-36$ & $56-116$ & $116-144$ & $144-258,5$ & $\begin{array}{l}258,5- \\
292\end{array}$ & $\begin{array}{l}292- \\
301\end{array}$ & \\
\hline
\end{tabular}

Nas tabelas 3 a 7 são utilizadas as seguintes abreviações:

CC - Cruzadas cavalgantes;

CTO - Cruzadas truncadas por ondas;

CGSF - Clásticos grossos penetrando, abaixo, em clásticos finos;

MCL - Mistura caótica de litologias;

CGEF - Clásticos grossos envolvidos por clásticos

finos;

Sep. granul. - Separação granulométrica;

Estrat. - Estratificação;

Granod. ou Granodecres. - Granodecrescência;

Ascend. - Ascendente;

Descend. - Descendente;

Ondul. - Ondulação ou onduladas;
Desarm. - Desarmônica;

Atect. - Atectônica;

Sedim. - Sedimentar;

Escav. - Escavação;

Preench. - Preenchimento;

Frag. - Fragmento;

Arg. - Argilito;

Lamin. - Laminação;

Inclin. - Inclinadas;

Slick ou slicken - "Slickensides";

Diast. - Diastema;

Cruz. - Cruzada;

Torc. - Torcidas;

Argil. - Argilosos;

Cresc. - Crescimento. 
município ou distrito, ao segundo se atribui o número dois. Por exemplo, $C-l G / 89$ e $C 2-l G / 89$, para os dois poços perfurados no município de Capivari em 1989.

B - Registro das colunas litológicas - Três tipos de fichas e uma tabela são utilizados para registro das sucessões litológicas.

A ficha intitulada Análise dos Testemunhos é utilizada para se plotar, no local do poço, as litologias e as estruturas, distribuídas de metro em metro, cada ficha abrangendo vinte e cinco a trinta metros. A Fig. 2 é exemplo de uma dessas fichas.

Nesta ficha menciona-se a quadrícula do IBGE, na escala 1:50.000, onde está situado o poço, a localidade de perfuração, o município, a cota da boca do poço, o número da folha da ficha (no exemplo citado a segunda folha da ficha - C-IG/86 - deste poço), intervalo 31 a $60 \mathrm{~m}$, as unidades litológicas atravessadas neste poço neste intervalo, o nome do geólogo que descreveu a coluna litológica, a data em que foi efetuada a descrição, as coordenadas do poço em UTM, as profundidades das amostras dos testemunhos trazidas para a sede (exemplo, C-32, amostra coletada a $32 \mathrm{~m}$ de profundidade) e avaliação aproximada das variações granulométricas, com a profundidade. Quando há interesse em se fornecer pormenores sobre as estruturas presentes em determinado intervalo, esquemas das estruturas são colocados no verso da ficha.

Descrição mais minuciosa das amostras, selecionadas como mais representativas e trazidas para a sede, consta de outra ficha, onde são tabulados a litologia predominante, o grau de seleção do testemunho, litologias associadas (no caso de existirem), estruturas e cor do sedimento seco, utilizando-se da Carta de Coloração de Rochas (GODDARD, 1970). A Tabela 2 constitui exemplo de uma dessas fichas.

\section{PERFIL CONDENSADO DOS POÇOS}

A partir dos dados obtidos através dos dois tipos de fichas supramencionados, foram construídos os perfis condensados dos poços, aqui reproduzidos para todos os poços da região Capivari-Rafard, com exceção dos poços $J-I G / 86$ e $C-I G / 90$, reproduzidos em PETRI \& PIRES (1992, no prelo).

A - Poço R-IG/85 (Fig. 5) - Este poço caracteriza-se por relativa regularidade de sucessões de termos litológicos. Diamictitos, em geral arenosos, só ocorrem em espessuras reduzidas. Contudo, clastos facetados e estriados foram encontrados em R 172 e R 152,5. A distribuição das estruturas sedimentares nos sedimentos deste poço está sintetizada na Tabela 3.
O pacote litológico pode ser dividido nos seguintes intervalos, numerados de baixo para cima:

Intervalo I, 301-292m - Predominantemente constituído de diamictito arenoso com clastos esparsos e filmes argilosos. Passa, irregularmente, para arenitos e siltitos. Estão presentes algumas laminações cruzadas acanaladas. Os dois últimos metros basais deste poço são constituídos de lamito contendo alguns grânulos.

Intervalo II, 292-258,5m - Clásticos finos, predominantemente constituídos de siltito contendo, vez ou outra, filmes argilosos. São relativamente comuns falhas de crescimento e outras estruturas de deslize, conduzindo à fluidificação. Laminações cruzadas são muito raras.

As condições de deposição seriam de águas calmas e os deslizes possivelmente causados pelo aumento de espessura dos sedimentos pela própria sedimentação. Entre 286 e $290 \mathrm{~m}$ ocorre, em contraste com as características gerais deste intervalo, arenito muito fino, sacaróide, maciço, com pouca matriz.

Intervalo III, 258,5-144m - Corpo bem individualizado, caracterizado por clásticos grossos: diamictitos e arenitos conglomeráticos a médios. Muito subordinadamente ocorrem arenitos finos a muito finos. Presença regular de filmes argilosos. Os diamictitos são arenosos, ocorrendo clastos facetados e, ocasionalmente, estriados.

Este intervalo é tipicamente caracterizado por grande número de granodecrescência ascendente se sucedendo através de pacotes de pequenas espessuras, cada granodecrescência separada da seguinte por diastema. Algumas laminações cruzadas cavalgantes ("climbings"), falhas de crescimento, dobras recumbentes e fluidificações também foram verificadas.

As condições de deposição teriam se verificado através de águas de energia elevada, desenvolvendo-se sob a forma de diversos fluxos de corrente, iniciando-se com águas carregadas de detritos que iriam, gradativamente, perdendo a carga até que incidiriam erosão e diastema.

Intervalo IV, 144-116m - Caracteriza-se por arenito de granulação média, com filmes argilosos em freqüência variável, aparecendo sob a forma de ondulações desarmônicas. Ritmitos aparecem muito esporadicamente, sendo constituídos de lâminas de arenito e de siltito. Estruturas como granodecrescência e falhas são pouco freqüentes. Foi registrado somente um diastema a $117 \mathrm{~m}$.

O ambiente de deposição seria transicional entre o intervalo III e o V, ou seja, deposição através de correntes de intensidade menos enérgica 
do que as que caracterizam o intervalo III mas mais enérgicas do que as do intervalo $\mathrm{V}$.

Intervalo V, 116-56m - Caracteriza-se pelo predomínio de clásticos finos, siltitos com ou sem filmes argilosos e, subordinadamente, argilitos, em corpos contínuos ou em lentes. Ocasionalmente ocorrem camadas irregulares de arenito fino a muito fino, onde podem aparecer, ocasionalmente, grânulos. Raras são as estruturas de deslize.

Os sedimentos deste intervalo devem ter sido depositados em condições de baixa energia, possivelmente em um mar relativamente restrito.

Intervalo VI, 56-39m - Freqüentes diamictitos associados a diastemas e granodecrescência de pequena espessura são característicos deste intervalo. Ocorrem estruturas ligadas a deslizes, lamitos engrouvinhados, clásticos finos fragmentados em ripas alongadas, freqüentemente deitadas segundo o acamamento. "Climbings" são imperfeitamente desenvolvidos. "Drags" são subordinados.

Correntes relativamente fortes ocasionando os freqüentes diastemas, associados a deslizes, devem ter prevalecido neste intervalo.

Intervalo VII, 39-9,60m - Predomina arenito muito fino com filmes argilosos em freqüência variável. Arenito fino a médio, siltito e argilito são subordinados.

As perturbações são pequenas; as camadas, geralmente, se dispõem em posição planohorizontal. Subordinadamente ocorrem argilitos engrouvinhados, brechas de argilito em arenito muito fino e falhas. Ocorrem microlaminações cruzadas por migração de marcas onduladas. Energia moderada deve ter prevalecido durante a sedimentação deste intervalo.

Considerações gerais - $\mathrm{O}$ conjunto litológico do poço evidencia flutuações maiores que os intervalos supradescritos, que lembram ciclotemas.

A partir da base, o conjunto de intervalos I e II caracteriza diminuição gradativa de energia do meio aquático ("Ciclotema" 1). Do mesmo modo, os intervalos III, IV e V formam um conjunto ainda mais nítido, "Ciclotema" 2 , que igualmente se inicia com sedimentação em meio aquoso de alta energia, refletida por sedimentos grossos e freøüentes diastemas e terminando com sedimentação em meio aquoso calmo. Finalmente o último conjunto de intervalos, VI e VII, repete a variação de ambientes de deposição, aquoso com mais energia para menos energia ("Ciclotema" 3). Não se trata de verdadeiros ciclotemas, razão das aspas.
B - Poço C-IG/86 (Fig. 6) - Este poço caracteriza-se por relativa uniformidade litológica, com tendência a se tornar mais grosso para o topo. Predominam arenitos muito finos com filmes argilosos. Notou-se a ocorrência de uma camada de arenito com cimento calcífero de 214 a $214,2 \mathrm{~m}$ de profundidade. O cimento poderia estar relacionado com diabásio eventualmente presente nas vizinhanças, visto que, pela nossa experiência, sempre que um poço perfurado na região corta diabásio, há ocorrências associadas de veios e cimento calcífero.

A seção litológica pode ser dividida em quatro intervalos, numerados de baixo para cima:

Intervalo I, 301-237m - Predominantemente constituído de arenito muito fino com ou sem filmes argilosos. Aparecem também, com certa freqüência, ritmitos e argilitos maciços. Estruturas de sobrecarga são relativamente freqüentes. Polígonos argilosos, com tendência a se acamarem, são mais raros.

Intervalo II, 237-203, 1m - A litologia predominante é lamito. Distingue-se do intervalo inferior pela presença de alguns diamictitos, pouco espessos, matriz lamítica ou arenosa, maciço ou com sugestões tênues de estratificação. Pode conter filmes e níveis argilosos fragmentados, cruzando o diamictito, horizontal e verticalmente, formando um retículo.

Intervalo III, 203,1-157m - Predominantemente constituído de arenito muito fino com filmes argilosos em freqüência variável. Pequenos seixos se distribuem esporadicamente neste arenito. Só ocorre um diamictito, próximo ao topo do intervalo, pouco espesso, de matriz lamítica e com sugestões de estratificação irregular, evidenciada por filmes pouco nítidos e interrompidos por manchas irregulares de arenito médio. $\mathrm{O}$ diamictito passa, através de granodecrescência ascendente, para arenito muito fino.

São freqüentes falhas com desenvolvimento de "slickensides" e "drags", dobras compostas de microdobras, argilitos amarrotados, porções de filmes rompidos, estirados, subverticais e fluidificação.

Intervalo IV, 157,1-10,5m (acima de 10,5m o sedimento está decomposto) - Predomina arenito de granulação variável, desde conglomerático até muito fino, com pequenos seixos esporadicamente distribuídos. Filmes argilosos se concentram em níveis irregularmante espaçados. Quatro corpos delgados de siltitos e ritmitos se distribuem no arenito à profundidade de $88 \mathrm{~m}$ a $152 \mathrm{~m}$. Delgados diamictitos com sugestões tênues de estratificação e de matriz arenosa aparecem em três níveis. 
Este intervalo é caracterizado por grande número de diastemas. Algumas granodecrescências, principalmente ascendentes, são registradas. Falhas, placas argilosas interrompidas, dobras assimétricas deitadas e fluidificações são comuns, bem como diversos tipos de laminações cruzadas.

Considerações gerais - As litologias e estruturas presentes no intervalo I sugerem ambiente gerador de águas de baixa energia, com correntes aquosas relativamente fracas. O empilhamento dos depósitos pouco consolidados produziria freqüentes estruturas de sobrecarga e algumas estruturas sugestivas de deslize. Os filmes e os polígonos argilosos, envolvidos por arenito, poderiam representar remobilizações de depósitos de lama de áreas laterais. A pequena freqüência de argila produziria filmes incompletos após o retrabalhamento.

As litologias e as estruturas do intervalo II são sugestivas de condições semelhantes às que presidiram a deposição do intervalo I apenas com ligeiro aumento de energia das correntes o que se refletiria no aumento da freqüência de clastos grossos, distribuídos pela matriz lamítica. Em alguns níveis, a sedimentação rápida produziu diápiros de argilito.

As relações entre os intervalos II e III são de granodecrescência descendente, o que sugere aumento da energia do meio aquoso.

Os freqüentes diastemas que caracterizam o intervalo IV são sugestivos de correntes relativamente fortes. Pequeno suprimento de clásticos mais finos seria o responsável pelas microlaminações cruzadas imperfeitamente desenvolvidas. A Tabela 4 evidencia maior ocorrência de estruturas sedimentares no intervalo IV. A ocorrência quase que exclusiva, neste intervalo, de estruturas interpretadas como derivadas de fluxos laminares, bem como a maior freqüência de estruturas interpretadas como originadas por deslizes, erosão e sedimentação rápida, são ressaltadas nesta tabela. A evolução dos depósitos do poço sugere que as condições foram ficando cada vez mais rasas para o topo.

C-Poço C-IG/87 (Fig. 7) - Caracterizase por intercalações de clásticos grossos e finos em toda a seção. Predominam arenitos muito finos com filmes argilosos em freqüência irregular.

A seção litológica pode ser dividida em sete intervalos, numerados de baixo para cima:

Intervalo I, 310-267,5m - Granodecrescência descendente a partir de siltito, passando para arenito muito fino e depois para arenito variando de fino a grosso e daí para diamictito arenolamítico com sugestões tênues de estratificação por variações granulométricas e pela presença de

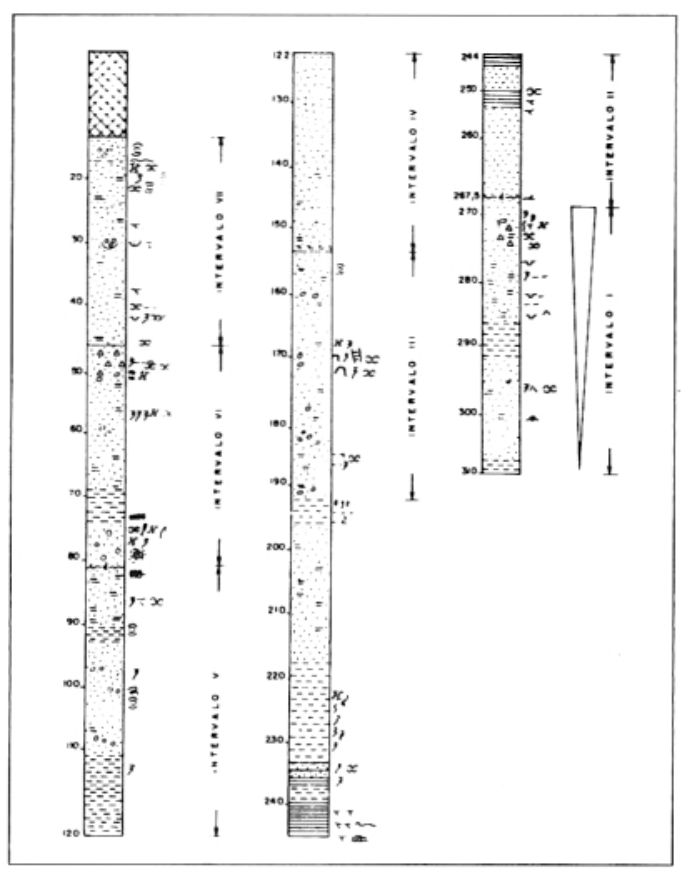

FIGURA 7 - Poço C-IG/87 - Perfil condensado.

filmes argilosos. Estes filmes evidenciam perturbações sob a forma de superfíceis irregulares no contato de duas litologias ou por filmes interrompidos, ondulados, inclinados e por "slickensides" nos níveis argilosos.

Intervalo II, 267,5-192m - Tendência para ritmitos tipo "varvito de Itu”, com intercalações de siltito. Na base ocorre arenito fino, micáceo e homogêneo. De 217 a 195,5m ocorre arenito fino, sacaróide, com intercalações irregulares de siltito e arenito muito fino.

Intervalo III, 192-153m - Predomina arenito muito fino, com filmes argilosos, podendo ocorrer, esporadicamente, seixos e calhaus.

Intervalo IV, 153-122m - Arenito médio a fino, sacaróide. Não ocorrem ou são muito raros filmes argilosos.

Intervalo V, 122-81m - Predomina siltito na base, até $101 \mathrm{~m}$, passando para arenito médio a grosso e muito grosso, feldspático, com pouca matriz e com clastos facetados e com intercalações de arenito fino, até $92,9 \mathrm{~m}$, quando então passa a predominar siltito, com intercalações de arenito fino a médio, sacaróide. Este intervalo está limitado, acima, por um diastema a $81 \mathrm{~m}$. Este é o intervalo mais heterogêneo do poço.

Intervalo VI, 81-46m - Acima do diastema ocorre conglomerado polimítico, com seixos de forma variada, dispostos subcaoticamente. Este conglomerado passa, irregularmente, a arenito médio sacaróide, até $75 \mathrm{~m}$, quando então dá 
TABELA 4 - Poço C - IG/86 - Estruturas Sedimentares.

\begin{tabular}{|c|c|c|c|c|c|}
\hline Boa sep. granul. & $33,2-103 ; 114-127,2$ & 171,$3 ; 180,1$ & & & \multirow{8}{*}{\begin{tabular}{|l} 
Fluxos \\
laminares
\end{tabular}} \\
\hline Estrat. cruzada & $\begin{array}{l}42-47 ; 55,5-60 ; \\
67-69 ; 79-81 ; 89 ; \\
94 ; 99,5 ; 103,5 ; \\
115,5 ; 144-144,5\end{array}$ & & & & \\
\hline "Climbings" & $\begin{array}{l}14 ; 33,2-39 ; 61-69 ; \\
71 ; 84-89 ; 97 ; \\
103,5 ; 115,5 ; 151,5\end{array}$ & & & & \\
\hline Marcas onduladas & 155 & & 238,5 & 276,3 & \\
\hline Granod. ascend. & \begin{tabular}{|l|}
$55-60 ; 68-69 ;$ \\
$99,5-103 ; 103,5 ; 109$
\end{tabular} & 163,8 & 237 & & \\
\hline $\begin{array}{l}\text { Granod. } \\
\text { descend. }\end{array}$ & 104 & & & & \\
\hline CTO & $65,5-69 ; 89,5 ; 101,9$ & & & 257,4 & \\
\hline Ondul. desarm. & $\begin{array}{l}55,5-69 ; 81-89 ; \\
99,5 ; 105,5-106,5 ; \\
123,7 ; 123,8 ; \\
143,3-143,9\end{array}$ & 185 & & $\begin{array}{l}239-240 \\
250,5-258,3 \\
276,3-277,4\end{array}$ & \\
\hline Ripas isoladas & $\begin{array}{l}\text { 53,5-60; 93-103,5; } \\
101,9-103,5 ; 110,2 ; \\
113,4 ; 123,7 ; 129,2 ; \\
143,3-144,5\end{array}$ & 173,$5 ; 203,1$ & 216,3 & $\begin{array}{l}240 ; 247 ; 250 \\
251,8 ; 252,5 \\
256,5-261,1\end{array}$ & Deslizes \\
\hline Pelotas de arg. & 127,$2 ; 149,4-149,8$ & & & $256,5-261,1 ; 251,8$ & \\
\hline Falhas atect. & $\begin{array}{l}14 ; 21 ; 114 ; \\
123,7-123,8 ; \\
143,3-144,5 ; 38 ; \\
130,5 ; 133 \\
\end{array}$ & \begin{tabular}{|l|}
$171,3-180,1 ;$ \\
$172,5-137,5 ; 188,1$
\end{tabular} & $227,8-230,8$ & 238,$5 ; 253 ; 254,5$ & \\
\hline Brecha sedim. & 130,$5 ; 131 ; 131,2$ & & & & \\
\hline Convolutas & $\begin{array}{l}21 ; 53,5 ; 89 ; 89,5 ; \\
93 ; 110,2 ; 120,2 ; \\
123,8 ; 143,9 ; 145\end{array}$ & & & $240 ; 270,5$ & \\
\hline CGEF & $93 ; 101,9 ; 103,5$ & & & & $\begin{array}{l}\text { Sedimentação } \\
\text { rápida }\end{array}$ \\
\hline CGSF & $\begin{array}{l}94 ; 123,8 ; \\
143,3-144,5\end{array}$ & 173,$5 ; 185$ & 232,5 & $\begin{array}{l}240 ; 254,5-261,1 ; \\
276,3-277,4\end{array}$ & \\
\hline Diápiro & 127,2 & & & $276,3-277-4$ & \\
\hline MCL & $\begin{array}{l}21 ; 61,5 ; \\
101,9-105,5 ; 110,2 ; \\
120,2-144,5\end{array}$ & $171,3-180,1 ; 185$ & & $\begin{array}{l}239-240 ; 250,5 ; \\
256,5-261,1 ; 270,5\end{array}$ & \\
\hline Diastema & \begin{tabular}{|l|}
$21 ; 24 ; 47 ; 55-69 ;$ \\
$89 ; 99,5-106,2 ;$ \\
$110-113,9 ; 131,2 ; 133$
\end{tabular} & 157,1 & & & Erosão \\
\hline Maciça & $142,5-142,8$ & & $\begin{array}{l}\text { 203-216,3; } \\
227-230,8\end{array}$ & $\begin{array}{l}\text { 273,7-288; 297-301- } \\
237(\mathrm{P})\end{array}$ & \begin{tabular}{|l|} 
Origens \\
diversas
\end{tabular} \\
\hline $\begin{array}{l}\text { Carvão(C)/ } \\
\text { Pista(P) }\end{array}$ & $\begin{array}{l}101,5-110,2 ; 127,2 \\
\text { (C) }\end{array}$ & $171-203,1$ & & & Orgânica \\
\hline Intervalo & $10,5-157-1$ & $157,1-203,1$ & $203,1-237$ & $237-301$ & \\
\hline
\end{tabular}


TABELA 5 - Poço C-IG/87 - Estruturas Sedimentares.

\begin{tabular}{|c|c|c|c|c|c|c|c|c|}
\hline Boa sep. granul. & $\begin{array}{l}13,8 ; 17-25 \\
37-46\end{array}$ & $46-48,5$ & 86 & & & & & \multirow[t]{8}{*}{$\begin{array}{l}\text { Fluxos } \\
\text { laminares }\end{array}$} \\
\hline Lamin. cruzada & $29-31 ; 37-42$ & & $82,9-83$ & & 182,7 & $\begin{array}{l}195,5 ; \\
240-244 ; \\
251-253 ; \\
267\end{array}$ & $267,5-271$ & \\
\hline $\mathrm{CC}$ & $37-42$ & & 92,9-98 & & 182,7 & & & \\
\hline Marcas ondul. & $13,8-16 \quad 19 ; 27$ & & & & $\begin{array}{l}169-171,5 \\
182,7\end{array}$ & 242 & & \\
\hline Granod. ascend. & & $50-53$ & 92-98 & & & & & \\
\hline Acomod. seixos & & 48,5 & & & & 243 & & \\
\hline CTO & & \begin{tabular}{|l|}
50,$5 ; 81$ \\
\end{tabular} & 82,9 & & 155 & & & \\
\hline Ondul. desarm. & $18 ; 23 ; 40-46$ & $\begin{array}{l}46-48,8 ; \\
58 ; 76,5 ; \\
81\end{array}$ & $\begin{array}{l}83 ; 86,3 ; \\
98,3 ; 122\end{array}$ & & $168-182,7$ & 195,$5 ; 249,8$ & $273-274,2$ & \\
\hline Ripas isoladas & 40 & 48,$5 ; 75$ & $\begin{array}{l}82,9-83,8 \\
98,3\end{array}$ & & 182,7 & $\begin{array}{l}194-195,5 \\
222 ; \\
233-235,5\end{array}$ & $296,5-306$ & \multirow[t]{5}{*}{ Deslizes } \\
\hline Ripas inclin. & & \begin{tabular}{|l|}
$50,5-53$ \\
58 \\
\end{tabular} & & & & $233-235,5$ & \begin{tabular}{|l|}
$273-274$ \\
282,5 \\
\end{tabular} & \\
\hline $\begin{array}{l}\text { Falhas-Slicken. (s) } \\
\text { arrasto (d) }\end{array}$ & $17-25$ & $\begin{array}{l}49,5 ; 58 ; \\
75(\mathrm{~s}) \\
76,5\end{array}$ & & & 168 & $222-223(d)$ & $\begin{array}{l}272,5- \\
273,8(\mathrm{~s})\end{array}$ & \\
\hline Brechas sedim. & & 73,5 & 98,3 & & & 195,5 & & \\
\hline Convolutas & 13,$8 ; 25$ & & $91 ; 98,3$ & & 169-171,5 & & & \\
\hline CGSF & $17-25$ & $\begin{array}{l}48,5 \\
78,5\end{array}$ & & & & & $\begin{array}{l}277,5 ; \\
282-283 \\
\end{array}$ & \multirow[t]{3}{*}{$\begin{array}{l}\text { Sedimentação } \\
\text { rápida }\end{array}$} \\
\hline Diápiro & & 49,5 & 83,8 & & & & 300,5 & \\
\hline MCL & $\begin{array}{l}17-25 \\
37-42\end{array}$ & $\begin{array}{l}49,5 ; \\
58-59 \\
75-76,5 \\
\end{array}$ & $\begin{array}{l}86,3 ; 97 \\
113-122\end{array}$ & & $\begin{array}{l}168-171,5 \\
182,7\end{array}$ & \begin{tabular}{|l}
195,$5 ;$ \\
$224-230 ;$ \\
235
\end{tabular} & $\begin{array}{l}270-272,5 ; \\
279 ; 296,5\end{array}$ & \\
\hline $\begin{array}{l}\text { Diast. escav. } \\
\text { preenc. }\end{array}$ & 30,5 & 78,$5 ; 81$ & & & & 267,5 & & Erosão \\
\hline Carvão & & & & & & 267,5 & & Orgânica \\
\hline Maciça & 30,5 & $\begin{array}{l}69-73,5 \\
80\end{array}$ & $\begin{array}{l}92-98 ; \\
105-122\end{array}$ & $122-153$ & & $\begin{array}{l}\text { 192-194; } \\
205-239 ; \\
246-267,5 \\
\end{array}$ & & $\begin{array}{l}\text { Origens } \\
\text { diversas }\end{array}$ \\
\hline Granod. desc. & & & & & & & $267,5-310$ & Progradação \\
\hline Intervalo & $13,8-46$ & $46-81$ & $81-122$ & $122-153$ & $153-192$ & $192-267,5$ & $267,5-310$ & \\
\hline
\end{tabular}

lugar a siltito até 68,5 . De 68,5 a $52 \mathrm{~m}$, comparece arenito fino a muito fino e, acima, até $46 \mathrm{~m}$, diamictito de matriz arenosa, com concentrações locais de clastos. Os clastos são facetados, angulosos, de litologias variadas.

Intervalo VII, 46-13,8m - Arenito muito fino a médio, com uma pequena estrutura de escavação e preenchimento, a 30,5m, ocupada por diamictito de matriz arenosa.

Acima de 13,8m, desenvolve-se regolito.

Considerações Gerais - Diamictitos maciços só ocorrem com espessuras reduzidas. Podese tomar como exemplo o que aparece a $48,5 \mathrm{~m}$. A matriz é arenosa, com concentrações locais de seixos de até $3,5 \mathrm{~cm}$ de diâmetro, com tendências a se acamarem no sentido de seu maior alongamento, embora globalmente a estrutura do diamictito tenda a maciça. Intercalam-se, ao diamictito, faixas arenosas com muitos filmes argilosos rompidos. Às vezes fragmentos argilo- sos se dispõem acima e abaixo de clastos; um, de granito, está envolvido por estes fragmentos, em maior número na sua parte superior. A inclinação dos fragmentos acompanha as irregularidades das superfícies inferior e superior do clasto. Ocorrem, também, faixas onduladas de arenito, com fragmentos argilosos, em contato irregular, tanto acima como abaixo, com o diamictito e, às vezes, línguas de arenito penetram no diamictito.

O intervalo IV, $153-122 \mathrm{~m}$, caracterizase por arenito médio. a fino, sacaróide, com filmes argilosos ou raras intercalações de siltito, de modo que a estrutưra geral é maciça, sem evidência de outras estruturas sedimentares. Contrasta com os intervalos acima e abaixo, evidentes na Tabela 5. Ao que parece, os sedimentos deste intervalo foram depositados rapidamente, o que teria impedido o desenvolvimento de outras estruturas. 
Evidências de erosão são muito raras em toda a seção do poço (v. Tabela 5). Por outro lado há abundantes evidências de ação de fluxos laminares e de deslizes. Estruturas como convolutas, pseudonódulos de arenito, ondulações desarmônicas, falhas, filmes argilosos interrompidos, sugerem torrentes de lama com clastos, penetrando em corpos de água de baixa energia, onde se estariam depositando os ritmitos e os siltitos. A grande carga de detritos provocaria os deslizes e fluidificação. Os deslizes são bem evidenciados por ripas individualizadas de sedimentos, inclinadas, como às profundidades, em metros, de 50,5-53; 58; 233-235,5; 273-274 e 282,5 , dobras deitadas a $98,3 \mathrm{~m}$ e dobras amarrotadas a $169-171,5 \mathrm{~m}$.

A granodecrescência descendente do intervalo I sugere progradação, culminando com o diastema da profundidade de $267,5 \mathrm{~m}$. Iniciar-seia, então, novo ciclo retrogradante, com elevada freqüência de clásticos finos (intervalo II) e nova tendência à progradação acima (intervalo III), não tão evidente como no intervalo I.

Não há, em toda a seção do poço, evidência de ação direta do gelo.

A coluna litológica deste poço, em alguns aspectos, exibe semelhança com a do poço $C-I G / 86$. São semelhantes, nos dois poços, a relativa uniformidade litológica e os delgados diamictitos, em parte estratificados.

D - Poço C-IG/89 (Fig. 8) - Este poço atingiu a profundidade de $275,5 \mathrm{~m}$. Predominam sedimentos arenosos. A proporção de clásticos grossos para finos é de 249,7/25,8, ou seja, mais de $80 \%$ da seção é constituída de clásticos grossos, principalmente arenitos, embora parte deles contenha filmes argilosos.

Diastemas não são comuns, embora úteis na subdivisão dos intervalos. São freqüentes granodecrescências ascendentes e descendentes. Com base nas granodecrescências e nos diastemas, a seção do poço foi dividida em nove intervalos, numerados de baixo para cima:

Intervalo I, 275,5-255m - Inicia-se com arenitos muito finos a médios, com raros filmes argilosos, passando para diamictitos de matriz arenosa. Através de granodecrescência ascendente, o diamictito passa para ritmito argilito/arenito e daí para folhelho argiloso.

Intervalo II, 255-201,5m - Na base deste intervalo ocorrem lamitos com clastos esporádicos, sem sinal de intemperismo; eles são angulosos, facetados, de diferentes litologias. O contato basal do lamito com o folhelho do intervalo I é irregular, em parte por sobrecarga, em parte por erosão e redeposição.

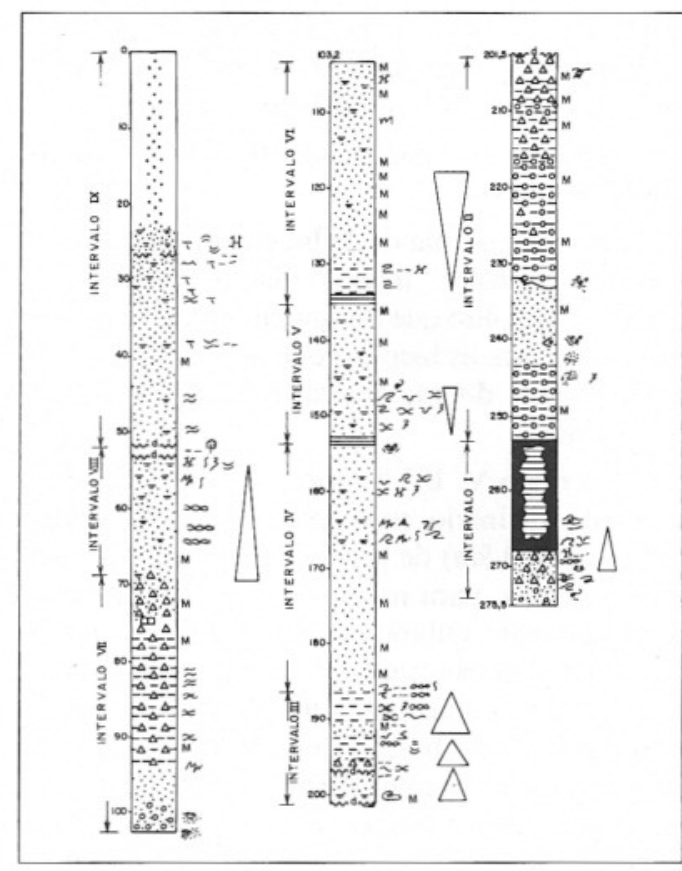

FIGURA 8 - Poço C-IG/89 - Perfil condensado.

O lamito é maciço, compacto, homogêneo, com foliação na base do pacote motivada por fino fraturamento horizontal. A $250,5 \mathrm{~m}$ de profundidade ocorre um clasto de granito róseo de 8 cm de diâmetro máximo, alongado, em posição vertical.

Este lamito basal é sucedido gradativamente para o topo, a partir de $246 \mathrm{~m}$, por arenito fino, maciço, o qual por sua vez passa gradativamente para lamito outra vez, até $216 \mathrm{~m}$, quando então é recoberto por diamictito maciço, com clastos angulosos e facetados, de diferentes litologias, matriz lamítica idêntica ao lamito de baixo, mostrando a continuidade das duas litologias.

O contato superior deste intervalo, a 201,5m, é de diastema.

Intervalo III, 201,5-186m - Caracteriza-se por sucessão de três pacotes com granodecrescência ascendente, com ou sem diastema. Os dois primeiros se iniciam com diamictitos de matriz arenosa passando, para o topo, para arenitos finos, homogêneos, maciços, com filmes e manchas argilosas distribuídas irregularmente. O pacote superior se inicia com arenito fino, com clastos e filmes argilosos passando, lateralmente, para diamictitos de matriz arenosa. Este conjunto de litologias grada, acima, para siltitos com filmes argilosos, cuja freqüência aumenta para o topo.

Intervalo IV, 186-153,5m - Constitui-se, essencialmente, de arenito muito fino, passando, esporádica e irregularmente, para siltito. Filmes 
argilosos, irregularmente distribuídos, só começam a aparecer de $167 \mathrm{~m}$ para cima. Abaixo de $167 \mathrm{~m}$, o arenito é homogêneo e maciço.

Em 153,5m aparece um bolsão de arenito conglomerático.

O pacote acima de $167 \mathrm{~m}$ é mais rico em estruturas: ocorrem "flames", diápiros de argilito, clastos de argilito que diminuem bruscamente de espessura para os lados, dique de arenito, dobras amarrotadas, dobras abertas e falhas de pequeno rejeito.

Intervalo V, 153,5-135m - Este intervalo é marcado, de início, pelo aparecimento de delgado pacote $(10,5 \mathrm{~m})$ de ritmito, talvez varvito, que passa, acima, para arenito muito fino, com intercalações irregulares de siltito. Filmes argilosos, relativamente freqüentes na base, diminuem para o topo caracterizando granodecrescência descendente. Na base do intervalo, onde os níveis argilosos são mais freqüentes, ocorrem largas dobras desarmônicas, dobras deitadas, dobras contendo microdobras, filmes interrompidos e falhamentos de pequeno rejeito.

Intervalo VI, 135-103,2m - Este intervalo exibe novo ciclo de granodecrescência descendente, começando com ritmito siltito/argilito passando, acima, para siltito que, por sua vez, passa para arenito arcosiano de granulação muito fina a média, com muita matriz.

No pacote basal de clásticos finos ocorrem estruturas complexas, com seqüência de dobras deitadas assimétricas, compostas por microdobras irregulares microfalhadas passando, lateralmente, para tratos tabulares interrompidos, irregularmente ondulados. Falhas inversas de pequeno rejeito e baixo ângulo também ocorrem; duas delas exibem traçados convergentes, isolando uma cunha.

Intervalo VII, 103,2-69m - Caracteriza-se principalmente por diamictitos e lamitos com clastos esparsos, às vezes em mistura caótica com arenito fino a muito fino com clastos esparsos. Subsidiariamente ocorre siltito, às vezes com cimento calcífero. A 101,2m de profundidade ocorre uma estrutura de escavação em arenito médio, preenchida por arenito conglomerático. À profundidade de $94 \mathrm{~m}$, camadas de arenito fino a muito fino se intercalam com lamito com clastos esporádicos, o conjunto disposto em dobras apertadas.

Intervalo VIII, 69-52m - Caracteriza-se por granodecrescência ascendente, do topo do intervalo VII à base do intervalo IX. O limite com este intervalo é de diastema. Caracteriza-se por arenito médio a fino, arcosiano, com muita matriz, passando acima para arenito muito fino com poucos filmes argilosos, cuja freqüência aumenta para cima quando, então, servem de superfícies de deslize de falhas, com "slickensides" se desenvolvendo em direções caóticas, resultando em amarrotamento de níveis argilosos que, em certas partes, se misturam caoticamente ao arenito.

Intervalo IX, 52-0m - Caracteriza-se, homogeneamente, por arenito muito fino, subsidiariamente, fino a médio, com muita matriz e filmes argilosos pouco freqüentes e de distribuição irregular. Quando não ocorrem filmes, a rocha é homogênea, maciça. De 38 a $23 \mathrm{~m}$, alternam-se pequenas laminações cruzadas não tangenciais, sem continuidade lateral, e largas ondulações irregulares. Ocorrem falhas de pequeno rejeito. A $28 \mathrm{~m}$, pequenas marcas onduladas assimétricas, irregulares. A $27 \mathrm{~m}$, um diastema. De 27 a 23m, conseqüências de microlaminações cruzadas acanaladas e algumas estratificações cruzadas truncadas por ondas. Acima de $23 \mathrm{~m}$ até a boca do poço, a recuperação da testemunhagem foi escassa mas, quando ocorre, os testemunhos são de arenito muito fino. A areia solta que apareceu em todo este pacote é de granulação fina.

Considerações Gerais - As granodecrescências descendentes, relativamente comuns de 254 a $118 \mathrm{~m}$, em diversos ciclos, sugerem fases de progradação sedimentar que poderiam ou não estar associadas a processos deltaicos.

Os depósitos mais espessos de clásticos finos, como visto, ocorrem na base. As outras intercalações de finos são mais delgadas. Os diamictitos maciços, lamíticos, são pouco espessos, passando para lamitos com clastos. No intervalo de 103,2 a 69m, ocorrem "mélanges" de diamictito, arenito e lamito, causadas, ao que parece, por variações bruscas da energia da água, talvez por fluxo turbulento.

O exame da Tabela 6 evidencia a abundância de estruturas sedimentares sugestivas de deslizes e sedimentação rápida.

No intervalo $I$, as estruturas sugerem corpo de água relativamente confinado, com invasão de correntes de densidade que teriam remanejado os depósitos, redepositando-os.

O intervalo II exibe grande diversidade de litologias. As suas estruturas sugerem invasões periódicas de fluxos de detritos e retrabalhamento de sedimentos finos, provavelmente situados nas bordas dos fluxos. A carga de detritos aumenta para o topo, culminando com diamictito.

Os sedimentos do intervalo III, com as sucessões de granodecrescências ascendentes, possivelmente se originaram de fluxos sucessivos de correntes de detritos, com diminuição gradativa de energia para cima em cada fluxo. 
A fonte arenosa do intervalo IV, de início homogênea, foi, posteriormente, de $167 \mathrm{~m}$ de profundidade para cima, diversificada por incremento de sedimentos argilosos, talvez pelo aumento do poder erosivo lateral dos fluxos de detritos. Aumentos locais de freqüência de sedimentos argilosos seriam os responsáveis pelas estruturas de sobrecarga, com "flames", diápiros e diques de arenito. Deslizes dos depósitos argilosos seriam os responsáveis pelas dobras apertadas. Os fluxos de detritos seriam mais uniformes do que no intervalo anterior (III).

No intervalo $\mathrm{V}$, aumenta a contribuição argilosa, em relação à parte superior do intervalo IV (a partir de $167 \mathrm{~m}$ ).
As irregularidades das estruturas da parte basal do intervalo VI (Fig. 8) sugerem deslizamentos mais freqüentes.

As passagens laterais irregulares de diamictitos, lamitos e arenitos do intervalo VII, formando "mélanges", seriam conseqüências de variações bruscas de energia da água, talvez por turbilhonamento.

A granodecrescência ascendente exibida pelos depósitos do intervalo VIII poderia representar um fluxo de detritos com energia diminuindo para o topo. Haveria, contudo, bruscos aumentos de energia próximo ao topo do intervalo, ocasionando os diastemas indicados na Fig. 8. Este

TABELA 6 - Poço C - IG/89 - Estruturas Sedimentares.

\begin{tabular}{|c|c|c|c|c|c|c|c|c|c|c|}
\hline Boa sep. gran. & $23-33,5$ & & $\begin{array}{l}99- \\
103,2\end{array}$ & & $\begin{array}{l}148- \\
152 \\
\end{array}$ & & & & 268,4 & \multirow[t]{7}{*}{$\begin{array}{l}\text { Fluxos } \\
\text { laminares }\end{array}$} \\
\hline Laminac. cruz. & $23-38,5$ & & & & & & & & 268 & \\
\hline Marcas ondul. & 28 & & & & & & 190 & & & \\
\hline Granod. ascend. & $26-27$ & 61-69 & $93-100$ & & & & $186-200$ & & $267-270$ & \\
\hline $\begin{array}{l}\text { Seixos } \\
\text { "pingados" }\end{array}$ & & & & & & & & & \begin{tabular}{|l|}
$264,5-$ \\
272
\end{tabular} & \\
\hline CTO & $25-26$ & & & & & & & & & \\
\hline Ondul. desarm. & $35-50$ & $60-64$ & $81,9-93$ & 103,2 & $\begin{array}{l}148- \\
153,5\end{array}$ & 159 & 186-196 & & $264-269$ & \\
\hline Ripas isoladas & $\begin{array}{l}27-38,5 \\
46-51\end{array}$ & $52-57,8$ & & 133,8 & $\begin{array}{l}135,8- \\
145 \\
153,5 \\
\end{array}$ & & $\begin{array}{l}186 ; 196 \\
191 ; 198\end{array}$ & & $\begin{array}{l}268- \\
268,5\end{array}$ & \multirow[t]{5}{*}{ Deslizes } \\
\hline $\begin{array}{l}\text { Ripas torc. (t) } \\
\text { inclinadas (i) }\end{array}$ & & & & & & $\begin{array}{l}167,8 \\
(t)\end{array}$ & $\begin{array}{l}200- \\
200,5(\mathrm{i})\end{array}$ & & & \\
\hline $\begin{array}{r}\text { Falhas normais } \\
\text { slick.(s) } \\
\text { arrasto(d) }\end{array}$ & $24-38,5$ & $\begin{array}{l}54-57,8 \\
\text { (s) }\end{array}$ & & $\begin{array}{l}106 ; \\
131\end{array}$ & 148 (d) & \begin{tabular}{|l|}
160,1 \\
$169,8(s)$
\end{tabular} & $186(\mathrm{~s})$ & $232(\mathrm{~s})$ & \begin{tabular}{|l|}
268 \\
$273-$ \\
$274(d)$ \\
\end{tabular} & \\
\hline Convoluta & & $\begin{array}{l}55,5 \\
54,5 \\
57,8\end{array}$ & 94 & $\begin{array}{l}133,8 \\
134 \\
133,8\end{array}$ & $\begin{array}{l}148,8 \\
153\end{array}$ & $\begin{array}{l}165 \\
167,8\end{array}$ & 194 & & \begin{tabular}{|l|}
271,5 \\
273 \\
267,6 \\
$268 ;$ \\
268,5 \\
\end{tabular} & \\
\hline Falha inversa & & & & 134 & & & 192 & & & \\
\hline CGSF & & & & $\begin{array}{l}133,8 \\
134\end{array}$ & \begin{tabular}{|l}
148 \\
150 \\
153,5 \\
\end{tabular} & $\begin{array}{l}159 \\
166\end{array}$ & $186-187$ & & $\begin{array}{l}255-269 \\
272-275\end{array}$ & \multirow[t]{4}{*}{$\begin{array}{l}\text { Sediment. } \\
\text { rápida }\end{array}$} \\
\hline Diápiro & & & & & & $\begin{array}{l}163,5 \\
165 \\
167,8 \\
\end{array}$ & 200 & & & \\
\hline Dique clástico & & & & & & 165 & & 203 & $\begin{array}{l}268 ; \\
269 \\
\end{array}$ & \\
\hline MCL & & \begin{tabular}{|l|}
54 \\
$60-64,2$ \\
\end{tabular} & \begin{tabular}{|l}
$75 ;$ \\
$83 ; 94$ \\
\end{tabular} & & $\begin{array}{l}148- \\
153 \\
\end{array}$ & $\begin{array}{l}159- \\
167,8\end{array}$ & \begin{tabular}{|l|}
$186-190$ \\
193 \\
\end{tabular} & 245 & \begin{tabular}{|l|}
267,6 \\
268 \\
\end{tabular} & \\
\hline Diastema & 27 & $52 ; 52,5$ & 101,2 & & 153,5 & 154 & $\begin{array}{l}196,5 \\
201 \\
\end{array}$ & $\begin{array}{l}231 ; 240 \\
243\end{array}$ & 270 & Erosão \\
\hline Vegetais foss. & & 52,5 & & & & & & & 268,4 & Orgânica \\
\hline Maciça & $40-42$ & 65,5 & \begin{tabular}{|l|}
$69-70$ \\
93 \\
\end{tabular} & $\begin{array}{l}103- \\
123\end{array}$ & \begin{tabular}{|l|}
$136-$ \\
146 \\
\end{tabular} & $\begin{array}{l}170- \\
182 \\
\end{array}$ & 191 & \begin{tabular}{|l|}
$202-240,5$ \\
$248-252$ \\
\end{tabular} & & $\begin{array}{l}\text { Origens } \\
\text { diversas }\end{array}$ \\
\hline Granod. desc. & & & & $\begin{array}{l}118- \\
134\end{array}$ & \begin{tabular}{|l|}
$146-$ \\
152 \\
\end{tabular} & & & $232,5-255$ & & $\begin{array}{l}\text { Prograda- } \\
\text { ção }\end{array}$ \\
\hline Intervalo & $23-52$ & $52-69$ & $\begin{array}{l}69- \\
103,2\end{array}$ & $\begin{array}{l}103,2- \\
135\end{array}$ & \begin{tabular}{|l}
$135-$ \\
153,5
\end{tabular} & $\begin{array}{l}153,5- \\
186\end{array}$ & $\begin{array}{l}186- \\
201,5\end{array}$ & $201,5-255$ & $\begin{array}{l}255- \\
275,5\end{array}$ & \\
\hline
\end{tabular}


aumento de energia seria espasmódico, visto que o intervalo IX é homogeneamente constituído por arenito predominantemente muito fino.

Os arenitos do intervalo IX exibem elevada freqüência de estruturas geradas por fluxos laminares, tais como laminações cruzadas, marcas onduladas e estratificações cruzadas truncadas por ondas, sugerindo que fluxos de detritos seriam negligenciáveis.

Em resumo, as litologias e as estruturas dos sedimentos deste poço sugerem presença de corpo relativamente confinado, de início sofrendo invasão de fluxos de detritos que passaram a predominar na maior parte da seção. Só no final, a partir de $52 \mathrm{~m}$ de profundidade, passariam a predominar regimes aquosos menos densos, sugeridos pela frequêencia de estruturas geradas por fluxos laminares.

E - Poço C2-IG/89 (Fig. 9) - Este poço atingiu a profundidade de $268 \mathrm{~m}$. A seção litológica é caracterizada por grande uniformidade litológica, com predomínio de clásticos de granulação de arenito a mais grossos. A proporção de clásticos grossos para finos é de 250/13.3, ou seja, mais de $93 \%$ da seção é constituída de clásticos grossos.

A seção litológica permite pronta separação em dois intervalos: o intervalo inferior é constituído, sobretudo, de ritmitos tipo varvito, com lâminas escuras de argilito e claras de arenito muito fino, apenas com $10 \mathrm{~cm}$ de argilito no topo. Sua espessura mínima é de 13,30m (268 a $254,7 \mathrm{~m}$ ) (intervalo I).

O intervalo II é constituído por clásticos mais grossos do que os do intervalo I.

Intervalo II, 254,7-4,8m - Acima de 4,8m aparece regolito. $\mathrm{O}$ intervalo II pode ser subdividido em três subintervalos; de baixo para cima, IIA, IIB e IIC.

Subintervalo IIA, 254,7-238m - Constituise, principalmente, de lamito cinza-médio, com grânulos e clastos maiores esporádicos, que podem, localmente, concentrar-se, tomando aspecto de diamictito. Subordinadamente ocorrem arenitos de granulação média, com clastos facetados de litologias variadas. Às vezes são observadas "mélanges" de lamito e arenito de granulação média, sugerindo fluidificação. A $238 \mathrm{~m}$ foi recuperado parte de um errático de granito cinza (cortado pela sonda), com diâmetro mínimo de $0,50 \mathrm{~m}$.

Subintervalo IIB, 238-34m - É o mais espesso. Caracteriza-se por arenitos e arcósios, com granulação variando de média a grossa; subordinadamente, conglomerática e de granulação fina, com raros e delgados diamictitos, descon-

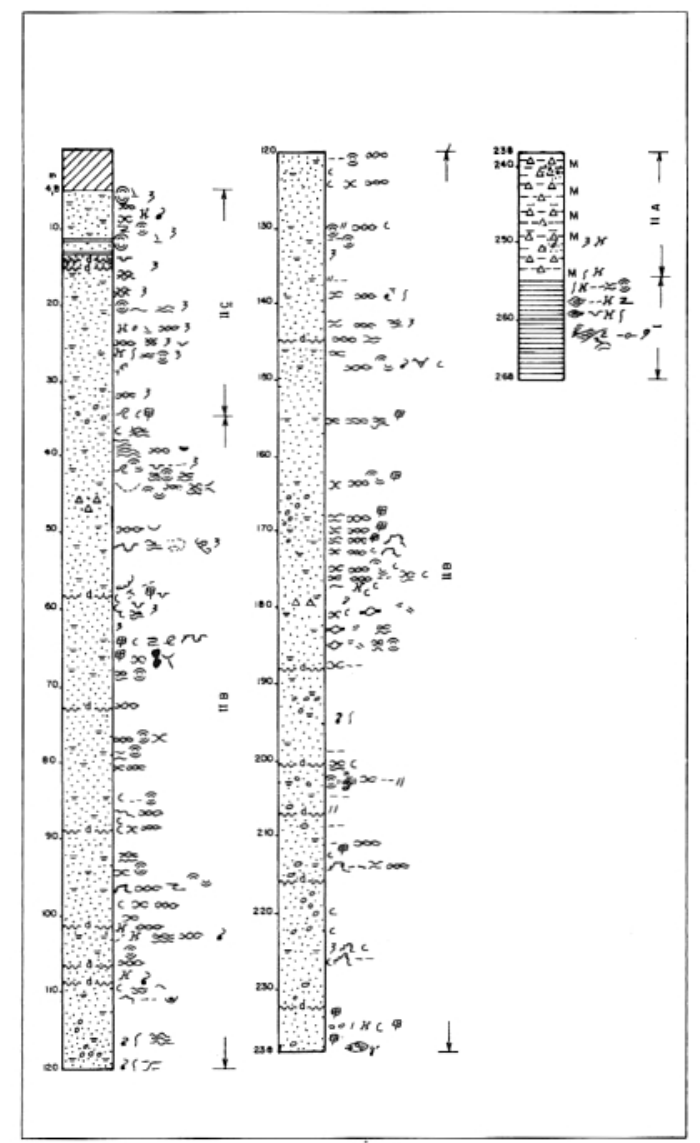

FIGURA 9 - Poço C2-IG/89 - Perfil condensado.

tínuos na horizontal, contendo clastos de litologias variadas, alguns facetados. Alguns destes diamictitos se caracterizam pela presença de argilitos constituindo os clastos maiores, alongados e angulosos. As variações granulométricas são irregulares. Freqüentemente os feldspatos estão caulinizados. Filmes argilosos são comuns mas irregularmente distribuídos, ora contínuos ora descontínuos, ora suborizontais ora inclinados e, às vezes, concentrados em manchas argilosas dentro do arenito. Dispõemse, com freqüência, em ondulações desarmônicas, entrelaçadas, em retículos confusos ou dispostos caoticamente, como "novelos de lã desmanchados".

Alguns arcósios grossos e conglomeráticos exibem seus clastos grossos com disposição caótica, associados a "tabulas" de carvão acamadas, sugerindo que correntes fracas remobilizaram o carvão, mais leve.

As falhas, em geral, são de pequeno rejeito e extensão lateral limitada, com freqüência, a camadas isoladas. Mais raramente seus traçados alcançam alguns centímetros e há um caso de convergência de falhas de maior persistência atra- 
vés das camadas. Poderiam estar presentes, portanto, falhas de acomodação, provocadas por pequenos deslizes de areia sobre argila, e falhas de escorregamento ao longo de paleodeclives.

Este espesso subintervalo se caracteriza pela presença comum dessas estruturas através de todo o pacote. Há feições sugestivas de fluidificação e sobrecarga. Parece ter havido remobilizações de arenitos contendo filmes argilosos, por fluxos turbulentos e freqüentes deslizes por excesso de sedimentação.

Subintervalo IIC, 34-4,8m - Predominam arenitos finos a muito finos, mal selecionados, com filmes argilosos distribuídos irregularmente. Ele é continuação do subintervalo IIB, apenas com granulação predominante mais fina. Não foram encontrados fragmentos carbonizados e plantas fósseis.

Parece ser evolução do subintervalo anterior, em meio aquoso de menor energia. Alguns testemunhos possuem filmes argilosos com freqüência maior que a regra, se tornando quase um ritmito.

A Tabela 7 condensa os dados sobre as estruturas dos sedimentos atravessados por este poço. Os intervalos correspondentes a I, IIA e IIC foram mantidos indivisos. Já a unidade IIB, por ser mais espessa, foi subdividada em nove partes.

Os ritmitos da unidade I teriam sido depositados em condições de costa afora, por mecanismos de correntes de turbidez. A energia do meio seria baixa. As perturbações que ocorrem no intervalo 255,3 a $263,5 \mathrm{~m}$, teriam sido originadas pela sedimentação lamítica da unidade situada logo acima (IIA).

Fluxos de detritos proximais, em relação aos turbiditos da unidade I, seriam os responsáveis pelos lamitos da unidade IIA. A estrutura é maciça, a não ser pela granodecrescência ascendente. Ocorrem falhas de crescimento e fluidificação.

A base da unidade IIB, 238 a 180m, se caracteriza por boa separação granulométrica das camadas, com estratificações cruzadas e, ocasionalmente, marcas onduladas, granodecrescências ascendentes e descendentes. São relativamente comuns fragmentos de carvão e vegetais carbonizados, havendo mesmo, esporadicamente, partes maiores de plantas carbonizadas. Diastemas, caracterizados por amplas depressões e cristas, ocorrem a 188, 201 e $207 \mathrm{~m}$, acima e abaixo de camadas de arcósio grosso em contato, tanto acima como abaixo, com arcósios de granulação média. Canais relativamente estreitos se desenvolveram sobre um diastema situado a $214 \mathrm{~m}$ de profundidade. Superfície largamente ondulada caracteriza um diastema que ocorre a $230,5 \mathrm{~m}$, separando arenito fino de médio. A $233,9 \mathrm{~m}$ ocor- re uma brecha sedimentar de espessura centimétrica. Estas características, tomadas em conjunto, sugerem canais provavelmente submersos.

A parte média da unidade IIB, 180 a $58,5 \mathrm{~m}$, não exibe evidências claras de estratificações cruzadas e as camadas não são claramente definidas, havendo passagens irregulares de granulometrias, na lateral. Ocasionalmente, contudo, ocorrem marcas onduladas. Por outro lado, estruturas interpretadas como causadas por deslizes, tais como falhas de crescimento e outras, são relativamente comuns. Sedimentação rápida, provocando estruturas como diápiros de lama, também ocorre. Diastemas, estratificações cruzadas truncadas por ondas, carvões e vegetais fósseis também são comuns.

O ambiente gerador de deposição dos sedimentos deste intervalo seria o de canais submersos, mais distais em relação aos canais geradores dos outros sedimentos da unidade IIB.

A partir de $58,5 \mathrm{~m}$ até $4,8 \mathrm{~m}$, na parte superior da unidade IIB e na unidade IIC, os testemunhos voltam a exibir boa separação granulométrica das camadas, estratificações cruzadas e marcas onduladas. Voltariam, portanto, a ocorrer condições mais proximais (Tabela $7 \mathrm{e}$ Fig. 9).

$F-P o c ̧ o C$-IG/90 - A ilustração da coluna litológica encontra-se em PETRI \& PIRES (1992).

Este poço só atingiu $101,4 \mathrm{~m}$ de profundidade. Sua seção litológica, ao contrário das de outros aqui estudados, é caracterizada pelo predomínio de sedimentos de granulação fina, ritmitos tipo "varvito de Itu" e argilitos. Clastos são, em comparação com os testemunhos de outros poços, pouco freqüentes e nunca de grande porte.

A proporção de clásticos grossos para finos é de $39,2 / 51$, ou seja, cerca de $43,3 \%$ da seção é constituída de clásticos de granulação maior do que silte.

Pode-se distinguir, com base na granulometria dos sedimentos, dois intervalos nítidos, com um terceiro de características intermediárias.

Intervalo I, 101,4-61,2m - Inicia-se na base do poço, até um diamictito que ocorre de 63 a $61,2 \mathrm{~m}$. A litologia predominante é arenito de granulação média a muito fina, com predominância de média na base e muito fina no topo. Arenito grosso é muito raro. Grânulos e seixos milimétricos são esporádicos. Filmes argilosos são raros na base, tornando-se mais freqüentes para cima, mas de forma irregular, imprimindo à rocha, às vezes, características de ritmito are- 


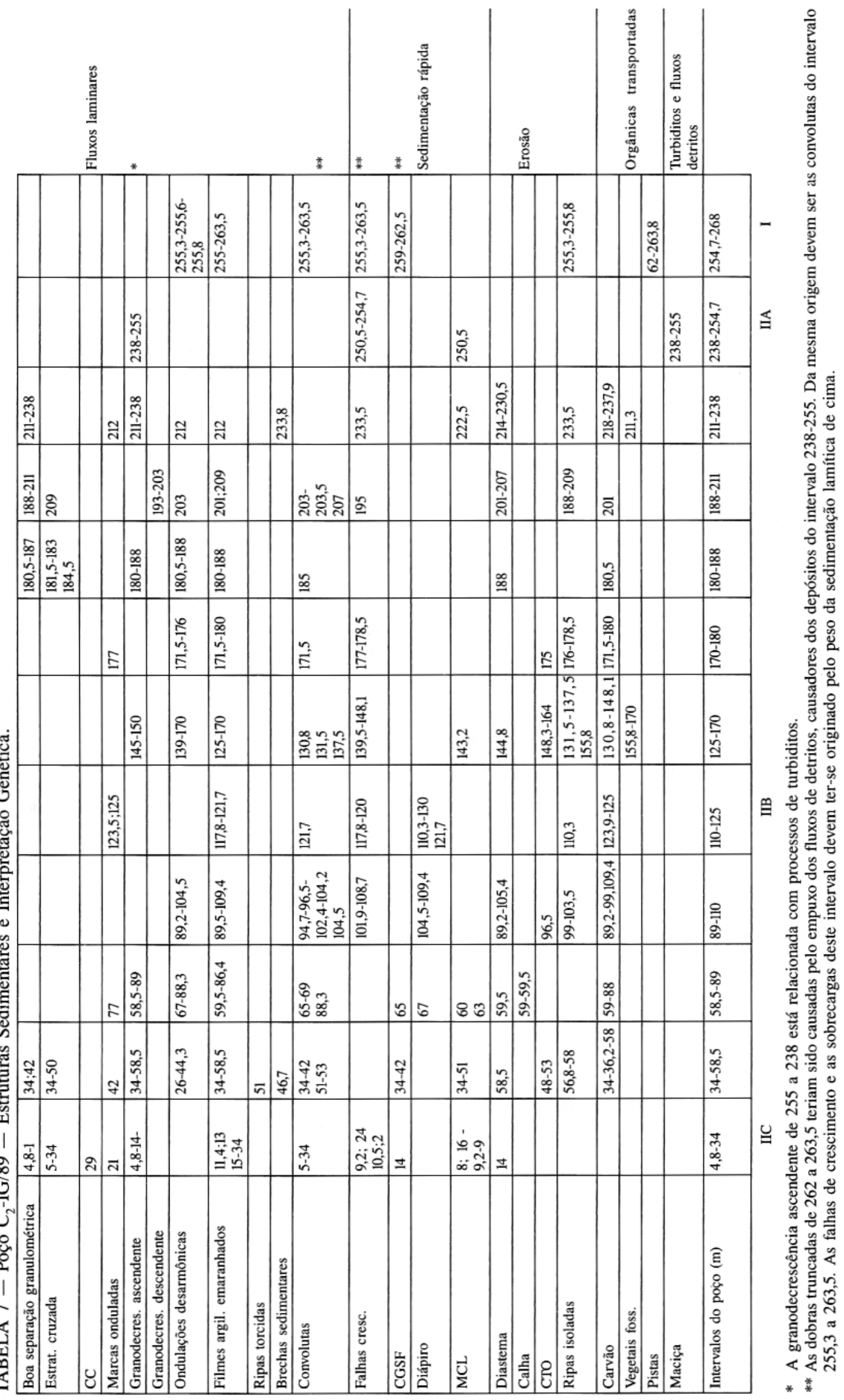


nito/argilito. Aparecem, em toda a seção, raros fragmentos argilosos.

Foram reconhecidos dois níveis delgados de diamictito, dos quais o mais importante é o do topo, que delimita este intervalo. Ambos os níveis exibem filmes argilosos esporádicos, o que imprime à rocha certa estratificação. $\mathrm{O}$ nível inferior, 84 a $83 \mathrm{~m}$ de profundidade, exibe pequenos seixos esparsos, com filmes argilosos se distribuindo em pequena estrutura convoluta, a $83,6 \mathrm{~m}$. O do topo, com $1,80 \mathrm{~m}$ de espessura, é arenolamítico, com fatias delgadas, descontínuas, de siltito e de material carbonoso, com tendência a se dispor horizontal ou inclinadamente. Comprova-se, portanto, a contribuição de correntes aquosas durante a deposição do diamictito.

Duas ocorrências de granodecrescência ascendente foram detectadas, sendo que uma terceira se inicia com o diamictito do topo, continuando com o intervalo de cima.

Dois diastemas, pelo menos, foram verificados neste intervalo. Passagens irregulares de litologias, bolsões de arenito de granulação média circundados por arenitos mais finos, fragmentos de arenito ou ritmito envolvidos por arenitos de outras granulações, às vezes com acomodações de sedimentos acima e abaixo, sugerindo canibalismo; falhas penecontemporâneas com ou sem "drags" de material argiloso, dobras anastomosadas e desarmônicas e convolutas sugerem deslizamentos subaquáticos. A $87 \mathrm{~m}$ de profundidade foi verificado um pequeno dique clástico de arenito.

As características deste intervalo sugerem um lobo arenoso submerso, avançando sobre um corpo de água de baixa energia possivelmente marinho, remobilizando, no caminho, sedimentos finos das bordas. Sedimentação rápida sobre detritos pouco coerentes seria responsável por freqüentes fluidificações.

Intervalo II, 61,2-42m - Este intervalo exibe características intermediárias entre os intervalos I e III. São freqüentes ritmitos tipo "varvito de Itu" (lâminas de siltito e argilito), intercalados em lamitos maciços com grânulos e pequenos seixos. O delgado diamictito do topo do intervalo I passa, gradativamente, para cima, para ritmito tipo "varvito de Itu". A 45,4m ocorre delgado diamictito, de $7 \mathrm{~cm}$ de espessura, lamítico, estratificado.

Incluem-se, entre as estruturas sedimentares deste intervalo, convolutas, ondulações desarmônicas de filmes argilosos, imbricamentos de fragmentos de siltito, filmes irregularmente anastomosados e porções de ritmitos destacados e ressedimentados. Diastemas ocorrem a 47, 50 e $59 \mathrm{~m}$.
Os sedimentos deste intervalo parecem refletir afogamento do lobo arenoso do intervalo I.

Intervalo III, 42-11m - É constituído, quase inteiramente, de ritmito tipo "varvito de Itu", com raros níveis de siltito e argilito. É um pacote homogêneo, quase sem estruturas sedimentares, a não ser a laminação, suaves ondulações e pequenas depressões de lâminas de argilito preenchidas por siltito, interpretadas como pequenas sobrecargas. Somente de $38 \mathrm{~m}$ para baixo, ocorrem outras perturbações, como seixos "pingados" com acomodações das lâminas acima e abaixo, pequenas convolutas, porções das lâminas destacadas em $S$, falhas penecontemporâneas, camadas truncadas de ritmito e "tabulas" do sedimento, com acomodações das lâminas acima e abaixo, sugerindo canibalismo.

A influência do lobo arenoso, neste intervalo, está restrita à profundidade de $38 \mathrm{~m}$. Acima desta profundidade foi completa a influência de águas calmas, com os sedimentos, possivelmente, depositados por mecanismos de turbiditos distais.

G-poço $M-I G / 85$ - A descrição litológica deste poço, perfurado na Fazenda São Gerônimo, município de Mombuca, é aqui incluída, tendo em vista o confronto com os poços da região Capivari-Rafard, embora este poço não esteja localizado nesta região (Figura 10).

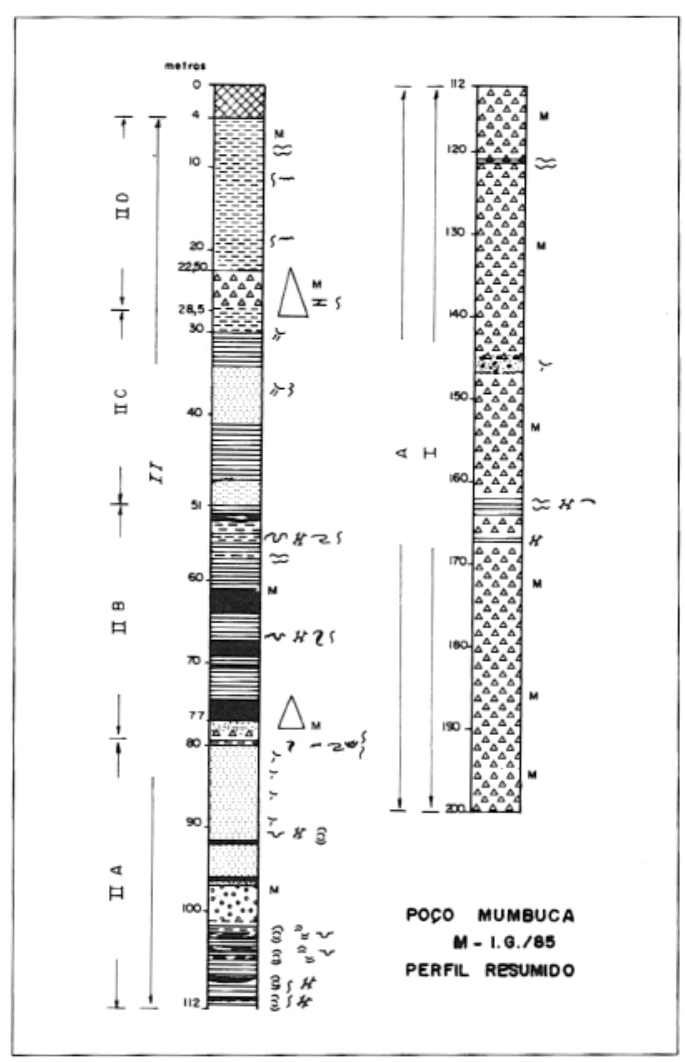

FIGURA 10 - Poço M-IG/85 - Perfil condensado. 
Este poço atingiu a profundidade de $200 \mathrm{~m}$ e foi interrompido quando a sonda estava cortando um diamictito de grande espessura (espessura mínima $88,00 \mathrm{~m}$ ), apenas com intercalações relativamente delgadas e subordinadas de outras litologias. Dos poços perfurados pelo Instituto Geológico, é este que exibe maior espessura de diamictitos. A proporção, no conjunto do poço, de diamictito em relação a outros clásticos é equivalente. Somando-se todos os níveis de diamictito neste poço, chega-se a um valor de $96,50 \mathrm{~m}$. Os clásticos finos, de argilito a arenito muito fino, somam $95,00 \mathrm{~m}$. Arenitos grossos totalizam apenas $4,50 \mathrm{~m}$. Os $4,00 \mathrm{~m}$ restantes para $200,00 \mathrm{~m}$ é do topo do poço, constituído de material decomposto.

A coluna litológica do poço propicia sua subdivisão em dois intervalos, de baixo para cima, chamados de I e II.

O intervalo I ( 200 a $112 \mathrm{~m})(88 \mathrm{~m})$ compreende uma única sucessão, $A$, constituída pelo diamictito basal, com inclusões bem subordinadas de clásticos mais finos. Este diamictito é maciço, de matriz lamítica, com clastos esporádicos de diversas litologias, angulosos e facetados, geralmente pequenos mas podendo atingir diâmetros que excedem $30 \mathrm{~cm}$. Os clásticos intercalados estão perturbados, com as camadas interrompidas e truncadas; raramente ocorrem argilitos amarrotados.

O intervalo II pode ser subdividido nos seguintes subintervalos, de baixo para cima: $A, B$, $C$ e $D$.

Subintervalo IIA: (1) $122,00-101,50 \mathrm{~m}$ $(10,50 \mathrm{~m})$ - Ritmito constituído de camadas ou lâminas de lamito e arenito muito fino, ocorrendo, também, siltitos e lamitos e, esporadicamente, lâminas de argilito.

(2) $101,50-97,00 \mathrm{~m}(4,50 \mathrm{~m})$ - Arenito sacaróide, grosso, com pouca matriz, maciço.

(3) $97,00-79,50 \mathrm{~m}(17,50 \mathrm{~m})$ - Arenito muito fino, com intercalações subordinadas de argilito, lamito, ritmito (lamito/argilito) e siltito.

O que caracteriza este subintervalo é a presença de estruturas enroladas, que foram chamadas, informalmente, de "rocambole" (estruturas convolutas), que ocorrem em toda a seção. Falhas irregulares, argilitos amarrotados, dobras de arrasto, sobrecargas, também são encontrados. Quando os clásticos são muito finos, os testemunhos são bastante fraturados, dificultando a recuperação. Estratificações cruzadas truncadas por onda ocorrem no pacote inferior (1) e conseqüências de laminação cruzada por migração de marcas onduladas, no pacote superior (3).
Subintervalo IIB: (1) 79,50-77,00m (2,50m) - Diamictito, matriz lamítica, passando, acima, para arenito grosso, feldspático e daí para lamito, em granodecrescência ascendente, que termina no argilito do pacote IIB (2). Ocorrem dobras recumbentes e falhas.

(2) 77,00-51,00m (26,00m) - Ritmitos tipo "varvito de Itu" e argilitos. Subordinadamente ocorrem siltitos. Os sedimentos finos são fraturados em "tijolinhos" dificultando sua recuperação. Ocorrem dobras desarmônicas e compostas com as camadas interrompidas e com espessuras variando irregularmente e exibindo estruturas de arrasto com estiramento dos leitos argilosos.

O que condicionou a união dos pacotes (1) e (2) no subintervalo IIB foi a granodecrescência ascendente.

Subintervalo IIC: $51,00-28,50 \mathrm{~m}(22,50 \mathrm{~m})-$ Arenito muito fino com filmes argilosos e, subordinadamente, arenito muito fino sem filmes argilosos, siltitos e argilitos. Ocorrem estratificações cruzadas planares, tangenciais, de tamanho médio, falhas de pequeno rejeito, dobras com ondulações desarmônicas, dobras assimétricas deitadas.

Subintervalo IID: (1)28,50-22,50m (6,00m) - Diamictito de matriz lamítica, maciço, foi encontrado um clasto estriado. Intercalações síticoarenosas e lentes síltico-argilosas ocorrem subordinadamente. Dique clástico e falha a $27,5 \mathrm{~m}$ de profundidade. Granodecrescência ascendente até o siltito de cima - IID (2).

(2) $22,50-4,00 \mathrm{~m}(18,50 \mathrm{~m})-$ Siltito homogêneo, maciço, com filmes argilosos irregularmente distribuídos. Os filmes podem ser interrompidos ou engrouvinhados. Ocorrem falhas.

O que condicionou a união dos pacotes (1) e (2) na sucessão IID foi a granodecrescência ascendente.

As litologias presentes neste poço sugerem a repetição constante de fluxos de detritos e que chegariam a uma região subsidente, com tendência a desenvolvimento de um corpo de água relativamente permanente.

As estratificações cruzadas, truncadas por onda do pacote IIA (1), conduzem à interpretação do corpo de água relativamente amplo e de profundidade suficiente para permitir a ação de turbilhonamento por ventos fortes sobre os sedimentos do fundo.

Os subintervalos IIA(2) e IIA (3) representariam flutuações para águas mais rasas, com desenvolvimento de estratificações cruzadas. 
As condições de deslizamentos de sedimentos semiconsolidados ao longo de declives causados pela própria sedimentação teriam permanecido durante todo tempo de sedimentação do pacote IIA, causando os "rocamboles".

O diamictito do subintervalo IIB (1) poderia ser produto de correntes de densidade; o clasto, excedendo $0,28 \mathrm{~m}$ de diâmetro, poderia eventualmente ter sido transportado no meio de uma massa detrítica concentrada, através de correntes de turbidez, só indiretamente ligada à glaciação. É o que foi deduzido tendo em vista a pequena espessura do diamictito $(1,00 \mathrm{~m})$ e seu cárater de granodecrescência ascendente. Este diamictito assenta sobre siltitos com filmes argilosos caoticamente dobrados no contato e com sugestões de dobras recumbentes e bolsões de conglomerados preenchendo escavações. Estas perturbações poderiam, eventualmente, ter sido causadas por empuxo de corrente de alta densidade.

As estruturas dos varvitos e argilitos de IIB (2) sugerem, da mesma maneira como no subintervalo IIA, que deslizes subaquáticos de material semiconsolidado continuaram prevalecendo durante todo o intervalo de tempo de sua sedimentação.

No subintervalo IIC também teriam prevalecido condições de correntes relativamente fracas proporcionando as laminações cruzadas por migrações de marcas onduladas e as evidências de deslizes, responsáveis pelas dobras deitadas e falhas.

O subintervalo IID (1) e (2) repete as condições de sedimentações do subintervalo IIB (1) e (2); o diamictito II D (1) aparece, contudo, com espessura maior. Também aqui ocorre granodecrescência ascendente para os clásticos finos do pacote II D (2) mas aqui as intercalações sílticoargilosas no diamictito ocorrem de forma lenticular e penetrando no diamictito sob forma de diques clásticos.

Verifica-se, portanto, que todo o intervalo II foi caracterizado pelo prevalecimento de condições de sedimentação por elevada carga de detritos, ocasionando declives por onde teriam ocorrido deslizes subaquáticos de material semiconsolidado. A subdivisão deste intervalo em subintervalos foi baseada na presença periódica de diamictitos com granodecrescência ascendente para clásticos finos. A litologia predominante neste subintervalo II foi, contudo, a de clásticos finos.

\section{COMPARAÇÃO LITOLÓGICA DOS POÇOS DA REGIÃO CAPIVARI-RAFARD}

Os seis poços estão localizados ao sul, sudeste e nordeste da conurbação Capivari-Rafard, envolvendo distâncias de 2 a 1,5 Km entre os quatro poços situados no lado sul, ou seja, $R-I G / 85$, $C-I G / 86, C-I G / 89$ e $C-I G / 90$, e $2 \mathrm{Km}$ entre os do lado norte, $C-I G / 87$ e $C 2-I G / 89$.

Entre $C-I G / 90$, do lado sul, e $C-I G / 87$, do lado norte, medeiam distância de pouco menos de $2 \mathrm{~km}$.

Os poços $C 2-I G / 89$, o mais afastado da área norte (nordeste), e $C-I G / 90$, são os que exibem maiores contrastes de litologia.

O poço $C 2-I G / 89$, diferentemente dos outros poços, caracteriza-se por grande espessura contínua de clásticos grossos, $250 \mathrm{~m}$, predominantemente constituídos por arenitos e, subordinadamente, lamitos com clastos esporádicos. Este é o poço de maior uniformidade litológica pelo lado dos clásticos grossos. A proporção de grossos para finos é de $250 / 13$, ou seja, $95 \%$ da coluna é constituída de clásticos grossos, sendo que os finos estão restritos aos $13 \mathrm{~m}$ basais do poço. É interessante ressaltar que a cerca de $2 \mathrm{~km}$ a nordeste deste poço, no $\mathrm{km}$ 127 da Rodovia do Açúcar, afloram diamictitos restritos a calhas escavadas em sedimentos argilosos, interpretados como depósitos a partir de fluxos de detritos que escavaram, subaquaticamente, as calhas, a partir de deslizes de grandes proporções. A projeção destas calhas para sudoeste passa pelo local do poço $C 2-I G / 89$, cujos depósitos poderiam estar relacionados a estes fluxos de detritos (PIRES \& PETRI, 1991). Chama a atenção, no pacote superior de clásticos grossos deste poço, a presença relativamente comum de fragmentos de carvão e de restos de plantas carbonizadas e a presença de feldspatos caulinizados.

O poço $C-I G / 90$ caracteriza-se, também, por grande uniformidade litológica mas para o lado dos finos. A proporção de grossos para finos é de $34 / 55$, ou seja, cerca de $38 \%$ é constituído de clásticos grossos. É interessante assinalar que, na estação de tratamento de água de Capivari, foi perfurado, antes de 1985, um poço pelo IG/SMA (TA, Fig. 11) cuja coluna litológica foi descrita por MANIAKAS (1986), sob a designação de IG-02. Verifica-se, pela descrição e ilustração de Maniakas, a predominância de arenitos neste poço, em grande contraste litológico com a coluna do poço $C-I G / 90$, embora diste apenas $500 \mathrm{~m}$ deste poço. Este poço, da estação de tratamento de água, bem como o poço de Capim Fino, cuja coluna litológica também foi descrita por Maniakas (op. cit.) como IG-01, são os dois únicos, estudados por este autor, que não foram aqui descritos por terem sido perfurados antes de 1985, quando ainda não estávamos no $I G-S M A$.

O poço Capim Fino, identicamente ao poço $C-I G / 90$, se caracteriza pela predominância de clásticos finos. Sua posição geográfica, bem dis- 
tante de outros poços aqui estudados, cerca de $2 \mathrm{~km}$ a sudoeste de $R-I G / 85$, se enquadra no esquema paleogeográfico da área, por nós proposto (ver, também, PIRES \& PETRI, 1991).

O poço $R-I G / 85$, referido por Maniakas (op. cit.) como $I G-05$, exibe proporções de clásticos grossos, em relação aos finos, de cerca de $57 \%$, o que o situa em uma posição intermediária entre os poços acima mencionados. Este poço, em contraste com todos os descritos até aqui, caracteriza-se por grande regularidade de sucessões de grossos e finos, com diastemas nas passagens de grossos para finos. Esta regularidade lembra ciclotemas.

Os poços $R-I G / 85$ e $C$-IG/90 exibem um pacote contínuo de clásticos finos, com espessuras equivalentes, em torno de $60 \mathrm{~m}$, e que, eventualmente, poderiam ser correlacionáveis no tempo, embora situados em cotas diferentes, mais alta em $C-I G / 90$.

Os sedimentos finos dos poços Capim Fino e $C-I G / 90$ foram interpretados como gerados em um mar onde imperariam condições de baixa energia. Também os sedimentos do poço $R-I G / 85$ teriam sido gerados em um mar de baixa energia. Contudo aqui as condições energéticas seriam periodicamente perturbadas por fluxos de detritos que atingiriam o mar através de canais submersos. Neste poço estas flutuações foram agrupadas em três episódios, caracterizados por diminuição gradativa de energia, refletida por granodecrescências ascendentes. Novo aumento de energia causaria diastema e, em seguida, novo episódio. Talvez toda a seção do poço $C-I G / 90$, que só chegou a $100,4 \mathrm{~m}$, possa ser correlacionada à parte superior, de águas mais calmas, do episódio intermediário do poço $R-I G / 85$. Este poço atingiu $301 \mathrm{~m}$ de profundidade.

Os sedimentos atravessados pelo poço $C 2-I G / 89$, gerados em condições de maior energia, foram interpretados como depósitos de fluxos de detrito em um canal submerso, que atravessou o local onde hoje se situa a cidade de Capivari e atingiu a região costa afora ao sul desta cidade. Este canal incorporaria, por erosão lateral, clásticos finos de suas margens, que se depositaram sob a forma de filmes.

O poço $C-I G / 89$ é o que está mais próximo, geograficamente, do afloramento com fósseis marinhos, distando deste cerca de $3 \mathrm{~km}$ no rumo noroeste. Este poço e os de sigla $C-I G / 86$ e $C-I G / 87$ possuem características intermediárias entre os poços Capim Fino, $C-I G / 90$ e $R-I G / 85$, de um lado, e os poços $T A$ e $C 2-I G / 89$ do outro. Os poços $C$-IG/86, $C-I G / 87$ e $C-I G / 89$ possuem cerca de $80 \%$ de clásticos grossos mas distribuídos de forma uniforme. Eles foram in- terpretados como gerados em condições de avanços e recuos de fluxos de detritos que adentravam o mar Capivari.

O poço $C$ - $I G / 86$ foi, parcialmente, descrito por Maniakas (op. cit.) como IG 0,4 até $240 \mathrm{~m}$ de profundidade. Posteriormente o poço foi continuado até $301 \mathrm{~m}$ de profundidade, como aqui descrito.

São características comuns aos poços da região aqui descritos: a) Freqüência de arenitos com intercalações argilosas, geralmente sob a forma de filmes dispostos irregularmente e também distribuídos de forma irregular. Esta litologia é a que comparece com maior freqüência; b) Diamictitos de matriz lamítica ou arenosa, sempre com espessuras reduzidas, interpretados como causados por correntes de densidade, sem relação direta com a glaciação, embora possa ser o resultado remoto de glaciação. Eles são, geralmente, maciços mas podem, esporadicamente, exibir filmes argilosos e, às vezes, passando, irregularmente, na vertical e (ou) na horizontal, para arenitos ou lamitos; c) Freqüência de estruturas interpretadas como causadas por deslizes subaquáticos por sobrecarga de sedimentos sobre uma rampa inclinada; d) Estruturas interpretadas como geradas por fluxos laminares ocorrem em posições estratigráficas definidas e são, proporcionalmente, menos freqüentes que as interpretadas como geradas por deslizes.

O estudo das colunas litológicas dos poços do médio Tietê corroboram as conclusões de GAMA et al. (1991) e PIRES \& PETRI (1991) de que não ocorrem sedimentos gerados diretamente por deposição glacial nesta região, embora possa haver remota ligação com os processos glaciais, provavelmente contemporâneos.

\section{PALEOGEOGRAFIA DA REGIÃO ESTUDADA, DE ACORDO COM OS POÇOS PERFURADOS PELO IG-SMA E TRABALHOS DE CAMPO}

Sugere-se que, no intervalo de tempo representado pelos sedimentos perfurados pelos oito poços aqui referidos, haveria persistência de condições marinhas costa afora no sul e centro da região de Capivari. A nordeste, norte e, possivelmente, a noroeste, ocorreriam condições mais proximais, representadas por lobos submarinos, dos quais o maior passaria pelo local de perfuração do poço $C 2-I G / 89$. Este lobo atravessaria o sítio urbano de Capivari, chegando ao "offshore" em uma área situada entre os sítios urbanos de Capivari e Rafard. Outro lobo passaria pelo poço $C-I G / 86$, possivelmente ligado ao primeiro através de uma área bordejando um canal 
mais profundo, passando pelo local do poço C-IG/90.

Este quadro paleogeográfico lembra o proposto por SOARES et al. (1977). O modelo destes autores envolve uma região maior do que a aqui estudada. Tendo em vista que se dispõe aqui de maior número de dados, foi possível elaborar um quadro mais pormenorizado de uma região menor (Fig. 11) (vide também PIRES \& PETRI, 1991). O mesmo pode ser aplicado para o modelo de STEVAUX et al. (1987), que também estudou área maior, envolvendo a área aqui estudada. Com dados à nossa disposição, não consideramos suficientemente documentada a existência de prodelta na região Capivari-Rafard, embora os fluxos de detrito aí reconhecidos, possam ter relações com possíveis deltas.

Os estudos de campo na região CapivariRafard demonstraram que os clásticos grossos se dispõem em canais escavados em argilitos, estes originados em um mar de baixa energia (Fig. 11).

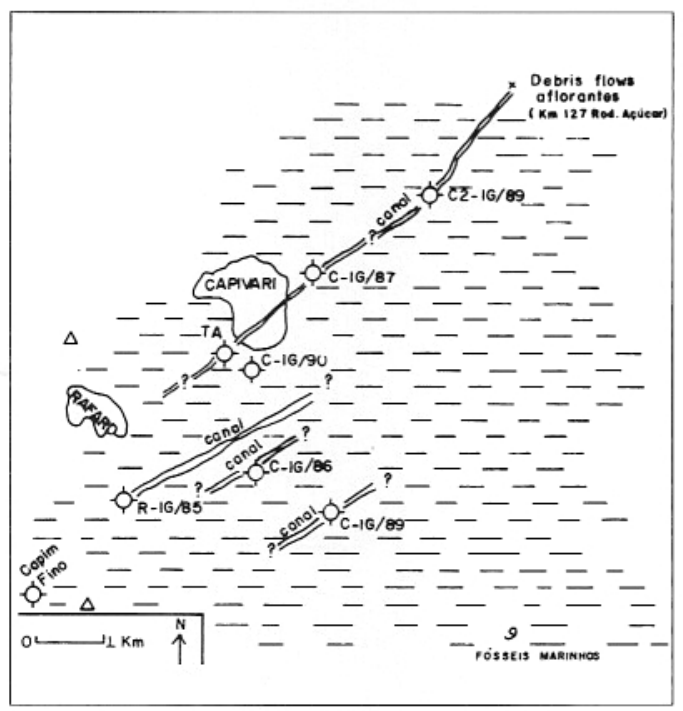

FIGURA 11 - Paleogeografia do Subgrupo Itararé na região Capivari-Rafard. Os traços horizontais se referem aos pelitos que caracterizariam o ambiente costa afora, de baixa energia.

Se se considerar, contudo, os seis poços desta área, por nós estudados a partir de 1985, verifica- se que a proporção de clásticos grossos (arenitos, lamitos com clastos e diamictitos) em relação aos finos (siltitos, argilitos e subordinadamente folhelhos) é de cerca de $71 \%$, valor da média de todos os poços. Esta porcentagem elevada demonstra que a freqüência de canais submarinos que atravessaram a região era muito grande, de modo que os depósitos de clásticos finos, originados no mar de baixa energia, aparecem subordinadamente.

A fácies $E$, descrita por PIRES \& PETRI (1991), na região Capivari-Rafard, constituída de diamictito lamítico maciço, ou lamito com clastos, cujas relações estratigráficas com outras fácies não ficaram claras no campo, aflora extensamente a noroeste da região, estando em contato com o diabásio na estrada para Mumbuca.

O poço M-IG/85, perfurado pelo IG/SMA na Fazenda São Gerônimo, em Mumbuca, atravessou espesso depósito de diamictito, com pelo menos $88 \mathrm{~m}$ de espessura, podendo ter maior possança, visto que o poço foi interrompido nesta litologia, a $200 \mathrm{~m}$ de profundidade. Este diamictito maciço, de matriz lamítica com clastos esparsos, alguns angulosos e facetados, geralmente pequenos, podendo contudo atingir $0,30 \mathrm{~m}$ de diâmetro, de litologias variadas, poderia, também, ser classificado como lamito conglomerático. Deve-se ressaltar que, de todos os poços perfurados pelo IG-SMA na região do médio Tietê, este é o único que exibe grande possança de diamictitos formando um corpo único.

Este espesso diamictito talvez possa ser correlacionado com a fácies $E$ de PIRES \& PETRI (1991) e com o "pebbly mudstone" do Membro Chapéu do Sol de FRANÇA (1987), topo do Itararé, segundo este autor. França o interpreta como depósitos formados através de geleira marinha, tendo em vista não só sua ampla distribuição, como também suas relações de interdigitação com a Formação Rio do Sul, do Sul do Brasil, contendo fósseis marinhos. Estes "pebbly mudstones" são extensamente distribuídos no Estado de São Paulo, segundo França (1987).

\section{REFERÊNCIAS BIBLIOGRÁFICAS}

FRANÇA, A.B. - 1987 - Stratigraphy, depositional environment and reservoir analysis of the Itararé Group (Permocarboniferous), Paraná basin, Brazil - Univ. Cincinnati Tese de doutoramento (inédita).

GAMA, Jr., E.G.; PERINOTTO, J.A.J. \& RI-
BEIRO, H.J.P.S. - 1991 - Contribuição ao estudo de parasseqüências no Subgrupo Itararé (P-C) no Estado de São Paulo. In: 2 ? SIMPÓSIO DE GEOLOGIA DO SUDESTE, Bol. Resumos, Sociedade Brasileira de Geologia, Núcleos São Paulo/Rio de Janeiro, p. 37. 
GODDARD, E.N. (Chairman) - 1970 - Rock Color Chart - Organizada pelo "The Rock Chart Committee" - Geol. Soc. Am.

MANIAKAS, S. - 1986 - Estudos geofísicos integrados à geologia da bacia hidrográfica do baixo rio Capivari, SP (Subgrupo Itararé e intrusivas associadas). Instituto de Geociências/USP. Tese de doutoramento (inédita).

PETRI, S. \& PIRES F.A. - 1992 - O Subgrupo Itararé $(\mathrm{P}-\mathrm{C})$ na região do médio Tietê, Estado de São Paulo (no prelo).

PIRES, F.A. \& PETRI, S. - 1991 - O Subgrupo Itararé na região de Capivari, SP - In: 2. SIMPÓSIO DE GEOLOGIA DO SU-
DESTE - Sociedade Brasileira de Geologia, Núcleos São Paulo/Rio de Janeiro, p. 37-38.

SOARES, P.C.; LANDIM, P.M.B.; SINELLI, O.; WERNECK, E.; WU, Fu-Tai; FIORI, A.P. - 1977 - Associações litológicas do Subgrupo Itararé e sua interpretação ambiental - Rev. Bras. Geoc. 7 (2): p. 131-149.

STEVAUX, J.C.; SOUZA Fo E.E.; TEIXEIRA, J.A.; LANDIM, P.M.B. - 1987 - Sistemas deposicionais do Subgrupo Itararé (P-C) na bacia hidrográfica do baixo rio $\mathrm{Ca}$ pivari, SP: um modelo para prospecção de água subterrânea - In: IV SIMPÓSIO REGIONAL DE GEOLOGIA, Sociedade Brasileira de Geologia. Núcleo São Paulo, Atas, vol. 2 , p. $355-374$.

Endereço do autor:

Setembrino Petri - Instituto Geológico - SMA - Caixa Postal 8772 - 04301-903 - São Paulo, SP - Brasil. 